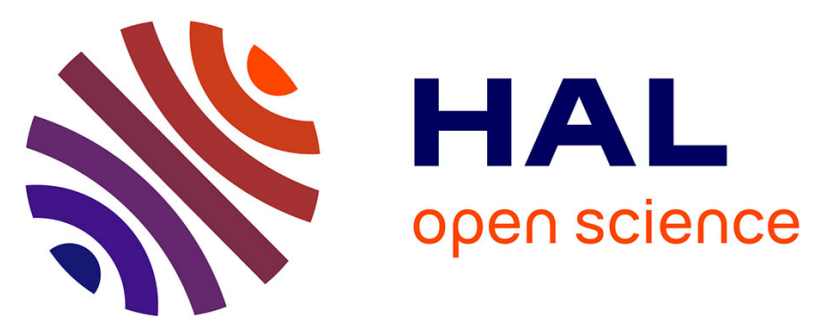

\title{
Hydrogen isotopic fractionations during syntheses of lipid biomarkers in the seeds of broomcorn millet (Panicum miliaceum L.) under controlled environmental conditions
}

Jérémy Jacob, Nicolas Bossard, Thierry Bariac, Valery Terwilliger, Philippe

Biron, Patricia Richard, Claude Le Milbeau, Elisabeth Vergès

\section{To cite this version:}

Jérémy Jacob, Nicolas Bossard, Thierry Bariac, Valery Terwilliger, Philippe Biron, et al.. Hydrogen isotopic fractionations during syntheses of lipid biomarkers in the seeds of broomcorn millet (Panicum miliaceum L.) under controlled environmental conditions. Organic Geochemistry, 2021, 154, pp.104221. 10.1016/j.orggeochem.2021.104221 . insu-03175971

\section{HAL Id: insu-03175971 \\ https://hal-insu.archives-ouvertes.fr/insu-03175971}

Submitted on 22 Mar 2021

HAL is a multi-disciplinary open access archive for the deposit and dissemination of scientific research documents, whether they are published or not. The documents may come from teaching and research institutions in France or abroad, or from public or private research centers.
L'archive ouverte pluridisciplinaire HAL, est destinée au dépôt et à la diffusion de documents scientifiques de niveau recherche, publiés ou non, émanant des établissements d'enseignement et de recherche français ou étrangers, des laboratoires publics ou privés. 


\section{Journal Pre-proofs}

Hydrogen isotopic fractionations during syntheses of lipid biomarkers in the seeds of broomcorn millet (Panicum miliaceum L.) under controlled environmental conditions

Jérémy Jacob, Nicolas Bossard, Thierry Bariac, Valery Terwilliger, Philippe Biron, Patricia Richard, Claude Le Milbeau, Elisabeth Vergès

PII: S0146-6380(21)00042-5

DOI: https://doi.org/10.1016/j.orggeochem.2021.104221

Reference: OG 104221

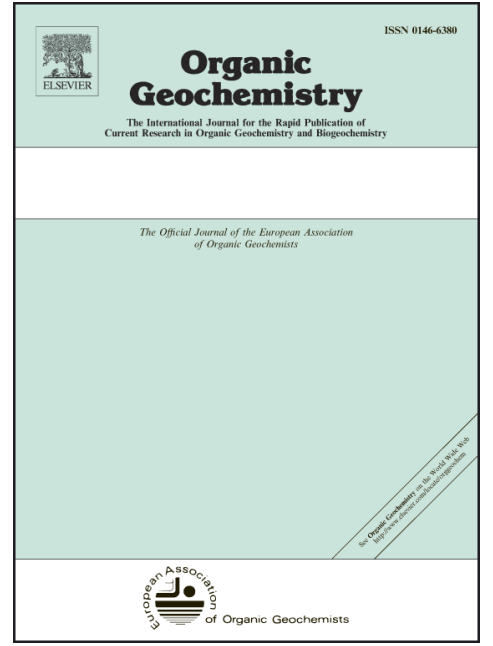

To appear in: $\quad$ Organic Geochemistry

Received Date: $\quad 1$ October 2020

Revised Date: $\quad 10$ March 2021

Accepted Date: $\quad 11$ March 2021

Please cite this article as: Jacob, J., Bossard, N., Bariac, T., Terwilliger, V., Biron, P., Richard, P., Le Milbeau, C., Vergès, E., Hydrogen isotopic fractionations during syntheses of lipid biomarkers in the seeds of broomcorn millet (Panicum miliaceum L.) under controlled environmental conditions, Organic Geochemistry (2021), doi: https://doi.org/10.1016/j.orggeochem.2021.104221

This is a PDF file of an article that has undergone enhancements after acceptance, such as the addition of a cover page and metadata, and formatting for readability, but it is not yet the definitive version of record. This version will undergo additional copyediting, typesetting and review before it is published in its final form, but we are providing this version to give early visibility of the article. Please note that, during the production process, errors may be discovered which could affect the content, and all legal disclaimers that apply to the journal pertain.

(C) 2021 Elsevier Ltd. All rights reserved. 
1 Hydrogen isotopic fractionations during syntheses of lipid biomarkers in the seeds of broomcorn

2 millet (Panicum miliaceum L.) under controlled environmental conditions

4 Jérémy Jacob ${ }^{\mathrm{a}, \mathrm{b}}$, Nicolas Bossard ${ }^{\mathrm{a}}$, Thierry Bariac ${ }^{\mathrm{c}}$, Valery Terwilliger ${ }^{\mathrm{a}, \mathrm{d}, \mathrm{e}, \mathrm{f}}$, Philippe Biron ${ }^{\mathrm{c}}$, Patricia

$5 \quad$ Richard $^{\mathrm{c}}$, Claude Le Milbeau ${ }^{\mathrm{a}}$, Elisabeth Vergès ${ }^{\mathrm{a}}$.

6

7 a Univ Orléans, CNRS, BRGM, Institut des Sciences de la Terre d'Orléans (ISTO), UMR

$8 \quad 7327,45071$ Orléans, France

$9 \quad{ }^{b}$ Laboratoire des Sciences du Climat et de l'Environnement, CEA-CNRS-UVSQ, Université

10 Paris-Saclay, 91198, Gif-sur-Yvette, France

11 'Institut d'Ecologie et des Sciences de l'Environnement - Paris, UMR 7618 CNRS-SU-UPMC-IRD-UPEC,

1278850 Thiverval-Grignon, France

$13{ }^{d}$ Le Studium, Loire Valley Institute for Advanced Studies, 1 rue Dupanloup, 45000 Orléans, France

$14{ }^{e}$ Department of Geography, University of Kansas, Lawrence, KS 66045, USA

$15{ }^{f}$ Department of Archaeology, Simon Fraser University, Burnaby, BC, V5A 1S6, Canada 
- Broomcorn millet was grown under controlled condition to examine fractionation of hydrogen isotopes during seeds lipid (miliacin and n-alkanes) synthesis

- Leaf water hydrogen isotopic composition is the primary driver of lipid $\delta^{2} \mathrm{H}$ values

- Apparent and biosynthetic fractionation could be calculated for n-alkanes and miliacin

- Subtle differences in biosynthetic fractionation between n-alkanes could reflect the impact of relative humidity, although both the experimental setup and the specific location of lipids analyzed (seeds) could have affected this relationship 
Abstract

Compound specific hydrogen isotopic analyses have the potential to reveal the biosynthetic pathways of biomarkers and to reconstruct the effects of water stress in a plant, or in an ecosystem. Although C4 graminoids are of great geological interest and are some of the world's leading crops, there are few experimental studies of their biomarker responses to hydrological conditions. Here, we study a C4 graminoid, broomcorn millet, and compare the effects of controlled changes in environmental conditions on the distributions of $n$-alkane homologues and on the pentacyclic triterpene, miliacin, which is a biomarker for broomcorn millet; both were measured in the seeds of the graminoid. Broomcorn millet plants were propagated in hydroponic solutions with four different $\delta^{2} \mathrm{H}$ values for each of two growth chambers, differing in relative humidity (58 and $74 \%$ ). Analyses of $\delta^{2} \mathrm{H}$ values of the lipid compounds (miliacin and $n$-alkanes) in seeds and water extracted from transpiring and non-transpiring organs allowed us to quantify the apparent (lipids vs. source water to plant) and biosynthetic (lipids $v s$. leaf water) fractionations during miliacin and $n$-alkane syntheses. Miliacin and $n$-alkane $\delta^{2} \mathrm{H}$ values were linearly related to leaf water $\delta^{2} \mathrm{H}$ values, permitting credible biosynthetic fractionations to be calculated for $n$-alkanes (average $-149.5 \% \pm$ 11) and miliacin $(-118 \% \circ \pm 5)$. These biosynthetic fractionations were within the range of published values for compounds with their respective biosynthetic pathways, although a ${ }^{2} \mathrm{H}$-enrichment of miliacin compared to $n$-alkanes remains unexplained.

Whereas a $16 \%$ decrease in relative humidity had no significant impact on the biosynthetic fractionation of miliacin, $n-\mathrm{C}_{25}$ and $n-\mathrm{C}_{27}$ alkanes, it led to a $\sim 25 \%$ decrease in biosynthetic fractionation for $n-\mathrm{C}_{31}$ and $n-\mathrm{C}_{33}$ alkanes. This could be the consequence of a contribution of more depleted pools of hydrogen atoms in cytoplasmic water (compared to chloroplastic hydrogen pools) during the $n$-alkyl lipid elongation process. This finding suggests that the respective influences of source water $\delta^{2} \mathrm{H}$ values and relative humidity on the $\delta^{2} \mathrm{H}$ values of organic compounds may be discretely inferred by examining the $\delta^{2} \mathrm{H}$ values of compounds synthesized from distinct sources of 
nyarogen in celis. It provides ciues to tne blosyntnetic Iractionations in a 44 plant tor compounas

53 derived from distinct pathways, but also highlights specific issues related to seed lipids that would require further research.

Key words: Biosynthetic fractionation; hydrogen isotopes; Panicum miliaceum; Biogeochemical chambers; compound-specific $\delta^{2} \mathrm{H}$, miliacin, biomarker. 
The hydrogen isotope ratios $\left(\delta^{2} \mathrm{H}\right)$ of lipids synthesised by autotrophs and preserved in geological archives are increasingly used to reconstruct past climates (reviewed by Sachse et al., 2012). These sedimentary lipids are produced by source organisms once living in the catchment and then transported, accumulating over time in sediments. When the conditions of their preservation are favorable, the isotope ratios of their C-bound hydrogen atoms may be unaltered over geological time (Yang and Huang, 2003). The rationale for using lipid $\delta^{2} \mathrm{H}$ values to reconstruct past climatic conditions rests on their ability to record the climatic conditions that prevailed at the time of biosynthesis (Sessions et al., 1999; Sauer et al., 2001; Huang et al., 2002; Gleixner and Mügler, 2007). An active area of research concerns the role that organism-level functional and biochemical fractionation has on proper interpretations of climate from lipid $\delta^{2} \mathrm{H}$ values in sedimentary archives. Precipitation water $\delta^{2} \mathrm{H}$ values are influenced by climatic variables; physical explanations for these relationships have long been established (Craig, 1961; Dansgaard, 1964). As the original source of hydrogen for the synthesis of lipids in autotrophs is precipitation water, the $\delta^{2} \mathrm{H}$ values of the lipids can potentially reflect the $\delta^{2} \mathrm{H}$ of precipitation and thus provide a quantitative indicator of climate variability (e.g., Gleixner and Mügler, 2007; Sachse et al., 2012).

Nevertheless, $\delta^{2} \mathrm{H}$ values of lipids are shaped not only by the $\delta^{2} \mathrm{H}$ values of precipitation, but also by additional factors. The identification and quantification of these factors is not only necessary to discern climatic information contributed by precipitation from $\delta^{2} \mathrm{H}$ analyses of lipid compounds, but may also lead to a wider range of climatic inferences. Understanding these factors thus remains a very active area of study (Sachse et al., 2012; Terwilliger and Jacob, 2013; Sessions, 2016).

Categories of factors that can affect the $\delta^{2} \mathrm{H}$ values of land-plant derived lipids include: (1) physical fractionations to hydrogen in water on its journey from precipitation to the site where it will be incorporated into organic compounds, and (2) fractionations during biosynthesis of compounds. The largest of the physical fractionations to water occur during the change of state 
Irom ilquid to vapor, auring wnicn liquid water becomes enricnea in moiecuies witn neavy isotopes because of the easier vaporization of water with light isotopes. The main state changes of relevance to land plants are during evaporation of surface soil water and during transpiration from leaves (e.g., Gonfiantini et al., 1965; Dongman et al., 1974; Farris and Strain 1978; Allison and Leaney, 1982). Water uptake by non-transpiring parts of plants remains isotopically similar to its sources in the soil (e.g., Ehleringer and Dawson, 1992; Bariac et al., 1994a;b). Evaporation and transpiration rates are, in turn, affected by environmental factors, such as temperature, relative humidity, net radiation and wind speed. The $\delta^{2} \mathrm{H}$ values of lipids synthesised by terrestrial higher plants thus integrate not only the $\delta^{2} \mathrm{H}$ values of precipitation, but also the climatic factors that drive rates of state changes to precipitation prior to the use of its hydrogen atoms in organic compound synthesis in the plant (Hou et al., 2007a,b; Gleixner and Mügler, 2007; Douglas et al., 2012; Sachse et al., 2012; Kahmen et al., 2013a,b; Tipple et al., 2015).

The extent to which the water providing hydrogen for photosynthesis will have been affected by the aforementioned physical fractionations may vary between plant types (i.e., Sachse et al., 2012). As most of the evaporation of soil water occurs at the surface and the more evaporation that occurs, the more difficult it is for plants to take up that water, the impact of evaporation on the $\delta^{2} \mathrm{H}$ of water will depend on root structure. Evapotranspiration causes ${ }^{2} \mathrm{H}$ enrichment of leaf water, although there is strong evidence that exposure to evapotranspiration is heterogeneous (Yakir, 1992). At present, evidence favors the hypothesis that for leaves of $\mathrm{C} 4$ grasses, water is more protected from evaporation in basal bundle sheath cells and mixed with non-evaporated xylem water, compared to water in mesophyll cells (Zhou et al., 2016; Gamara et al., 2016). Within cells, cytoplasmic water is more affected by evaporation than chloroplastic water (reviewed by Yakir, 1992).

Hydrogen fractionations during biosynthesis of compounds in a plant primarily involve enzyme preferences for specific hydrogen isotopes and bond positions during kinetic reactions (Estep and Hoering, 1980; Sessions 2016). Although the first source of hydrogen for synthesis of a 
intermediates (e.g., NADPH and metabolites) produced elsewhere in the plant, at a different time to that of the final compound synthesised, with distinct $\delta^{2} \mathrm{H}$ values, and in varying proportions (Sachse et al., 2012; Cormier et al., 2018). Thus, the exact climate information in the $\delta^{2} \mathrm{H}$ value of a compound will depend on where enzymatic reactions leading to its production take place in a plant. Efforts to identify the precise imprints of specific climatic factors on specific lipid compounds have largely centred on studies of $n$-alkyl lipids (e.g., $n$-alkanes, fatty acids), which are major components in the leaf waxes of many land plants (Eglinton and Hamilton, 1967; Diefendorf et al., 2011; Diefendorf and Freimuth, 2017). One approach has been to analyse the $\delta^{2} \mathrm{H}$ values of leaf waxes in plants and sediments over natural environmental gradients (e.g., Huang et al., 2002; Sachse et al., 2004; Sachse et al., 2006; Jia et al., 2008; Feakins and Sessions., 2010; Bai et al., 2011; Douglas et al., 2012; Garcin et al., 2012; Kahmen et al., 2013a). Another approach has been to extract specific $n$-alkyl lipids from leaf waxes of plant species grown under controlled environmental conditions (e.g., Zhou et al., 2011; Kahmen et al., 2013b; Gao et al., 2014; Tipple et al., 2015; Gamarra et al., 2016; Zhou et al., 2016). As these compounds are found in differing proportions across many different plant types, the results are limited in the extent to which they can be extrapolated to reconstruct climatic changes in systems where vegetation may also have changed (Hou et al., 2007b; Smith and Freeman, 2006; Liu and Yang, 2008; Polissar and Freeman, 2010).

Our study reports the effects of growing broomcorn millet plants at different $\delta^{2} \mathrm{H}$ values of hydroponic solutions (HS) and at different relative humidities, on the $\delta^{2} \mathrm{H}$ values of $n$-alkanes and of miliacin, both extracted from seeds. Miliacin (olean-18-en-3 $\beta$-ol ME; Fig. 1), a pentacyclic triterpene methyl ether, is a specific biomarker of broomcorn millet (Panicum miliaceum), which is a C4 plant. This biomarker was found in the sediments of lake Le Bourget dated as prior to the Bronze Age (Jacob et al., 2008a,b; 2009; Bossard et al., 2011; Bossard, 2013). It was also used as a tracer of C4 grasses in tropical soils (Schwab et al., 2015). The first objective was to determine the apparent (lipid $v s$. water source to plant; $\boldsymbol{E}_{\text {app }}$ ) and biosynthetic (lipid $v s$. leaf water; $\boldsymbol{E}_{\text {bio }}$ ) 
species. The second objective of our report was to quantify the effects of relative humidity on the apparent and biosynthetic fractionations of miliacin and $n$-alkanes. Our results suggest minute differences in the relationships of humidity to isotopic compositions between individual compounds extracted from the seeds of one $\mathrm{C} 4$ species.

\section{MATERIALS AND METHODS}

\subsection{Experimental design}

We quantified the impacts of two factors that contribute to the $\delta^{2} \mathrm{H}$ values of plant lipids: source water $\delta^{2} \mathrm{H}$ values (water taken up by plants) and relative humidity of the atmosphere surrounding plants. Millet plants were cultivated in two controlled climate growth chambers built for experiments on the isotopic consequences of the environment on plant physiology at the Institut d'Ecologie et des Sciences de l'Environnement (UMR 7618, Paris, France): RUBIC I (described in Rothfuss et al., 2010) and RUBIC V (Longchamp et al., 2015). RUBIC stands for Reactor Used for Continental Isotopic Biogeochemistry. We maintained relative humidities of $58 \%$ in the $0.5 \mathrm{~m}^{3}$ RUBIC I and of $74 \%$ in the $9 \mathrm{~m}^{3}$ RUBIC V (Fig. 2). The relative humidity of the air was precisely regulated in the different chambers by controlling the condensation temperature in a heat exchanger. The excess moisture condensed and was then discharged to the outside, thus providing excellent stability of the relative humidity of the air. We sampled the condensate at the end of each day to analyse its isotopic composition. The air temperature was regulated by the volume of air flowing through the heat exchanger. One of the particularities of the RUBIC chambers is that the vapor they contain is not only a driver of transpiration (through a vapor pressure deficit), but is also a resulting effect of condensation (heat exchanger). Otherwise, the environmental conditions were the same in the two chambers: a photoperiod of 12 hours per 24 (at $600 \mu \mathrm{mol} / \mathrm{m}^{2} / \mathrm{s}$ photosynthetic photon flux density), a temperature of $18^{\circ} \mathrm{C}$ (night) and $25^{\circ} \mathrm{C}$ (day), and a slow wind speed $\left(0.1 \mathrm{~m} \mathrm{~s}^{-1}\right)$ to 
seeds (provided by Parard-Sévin, Mézières-lez-Cléry, France). Then, 5 plants were grown in 4 tanks with different $\delta^{2} \mathrm{H}$ values of water in hydroponic solutions. Four tanks (and hence 20 plants) were placed in each chamber. Hydroponic solutions were prepared with 8 stock solutions (4 per chamber) of ${ }^{2} \mathrm{H}_{2} \mathrm{O}$ and tap water of -50\% (V-SMOW; Vienna Standard Mean Ocean Water). The tanks containing hydroponic solutions were covered with plastic plates drilled with a single hole for each plant. These holes were plugged with rubber stoppers filled with Teroson ${ }^{\circledR}$ (sticky putty) to limit exchange between the hydroponic solution and surrounding air. In addition, each hydroponic solution was replaced weekly with stock solution to ensure that its isotopic composition remained constant (as described below).

\subsection{Water $\delta^{2} \mathrm{H}$ and $\delta^{18} \mathrm{O}$ analyses}

$\delta^{2} \mathrm{H}$ determination of water in hydroponic solutions and in plant organs allowed us to calculate apparent and biosynthetic fractionations. In addition, we determined $\delta^{18} \mathrm{O}$ values of the same waters to characterize the effects of transpiration. Water was extracted from one plant per treatment (relative humidity and $\delta^{2} \mathrm{H}$ value of the hydroponic solution) one week before seed harvest, which was when seeds were fully developed, but not dry. This was done to obtain enough water for isotopic ratio measurements. Water was extracted from the following organs of each plant: roots, first internode (collet) and other internodes, leaves and panicles (i.e., stems and spikelets composed of glumes, paleas and lemmas; Fig. 2). Water was extracted from the plant organs by cryogenic distillation and analyzed for $\delta^{2} \mathrm{H}$ and $\delta^{18} \mathrm{O}$ values (Araguas-Araguas et al., 1995). $\delta^{18} \mathrm{O}$ values were measured (analytical precision: $\pm 0.1 \%$ ) on an isotope ratio mass spectrometer (IRMS; Isoprime) coupled to an Aquaprep system and for $\delta^{2} \mathrm{H}$ on an IRMS PyrOH (Isoprime, analytical precision: \pm $1 \%$ ) coupled to an elemental analyzer (Eurovector). $\delta^{2} \mathrm{H}$ and $\delta^{18} \mathrm{O}$ values of hydroponic solutions 


\subsection{Extraction and purification of compounds}

We analyzed lipids from the seeds because Bossard et al. (2013) showed that miliacin is very abundant in $P$. miliaceum seeds, but has negligible concentrations elsewhere in the plant. In addition to miliacin, seeds contain other lipids, such as $n$-alkanes. Seeds were harvested when they were fully developed and the plants had become dry. The seeds from one to three plants that had sufficient seeds to yield enough of the compounds for analysis were sampled per treatment $\left(\delta^{2} \mathrm{H}\right.$ value and relative humidity) for replication. For each plant, about 40 seeds of the main panicle were ground to a powder and weighed. Lipids were extracted by immersing each seed sample in dichloromethane:isopropanol $(2: 1 \mathrm{v}: \mathrm{v})$ and sonicating for 5 minutes, 3 times, before centrifugation. For each plant, the lipid extracts were combined and dried under a stream of $\mathrm{N}_{2}$ gas. The total extract was separated into neutral, acidic and polar fractions by ion exchange chromatography on aminopropyl-bonded silica, as per Jacob et al. (2005). The different classes of compounds ( $n$ alkanes and miliacin) were purified from the neutral fraction by flash chromatography on activated silica using solvents of increasing polarity (as per Bossard et al., 2011). Aliphatic hydrocarbons, such as $n$-alkanes, were first eluted with $2 \mathrm{~mL}$ of heptane, then aromatic hydrocarbons were eluted with $1 \mathrm{~mL}$ heptane and then $2 \mathrm{~mL}$ heptane:toluene 2:1. Miliacin was eluted with $2 \mathrm{~mL}$ hexane:toluene (1:1) and $2 \mathrm{~mL}$ hexane/ethyl acetate (19:1). The different fractions were dried under a stream of tank nitrogen and stored at $4{ }^{\circ} \mathrm{C}$ until analysis.

\subsubsection{Compound quantitation and purity assessment}

The abundance and purity of miliacin were assessed by gas chromatography-mass spectrometry (GC-MS) on a Trace gas chromatograph coupled to a Polaris GCQ ion trap mass spectrometer (both from Thermo Scientific, Bremen) according to the protocol of Jacob et al. (2005). 5 $\alpha$-cholestane was added prior to analysis by GC-MS, for quantification. The gas 

$40^{\circ} \mathrm{C}$ for $1 \mathrm{~min}$, and then increased from 40 to $300^{\circ} \mathrm{C}$ at a rate of $20^{\circ} \mathrm{C} \mathrm{min}-1$, with a final isothermal hold at $300^{\circ} \mathrm{C}$ for $30 \mathrm{~min}$. The sample was dissolved in toluene and injected splitless in a $2 \mu \mathrm{L}$ volume with injector temperature set at $280^{\circ} \mathrm{C}$. The carrier gas was helium at a flow rate of $1.4 \mathrm{~mL}$ $\min ^{-1}$. The mass spectrometer was operated in the electron ionization (EI) mode at $70 \mathrm{eV}$ ionization energy and scanned from $\mathrm{m} / \mathrm{z} 50$ to 650 .

\subsubsection{Compound-specific $\delta^{2} H$ measurements}

$\delta^{2} \mathrm{H}$ values of miliacin and $n$-alkanes were determined by gas chromatography-stable isotope ratio mass spectrometry (GC-irMS) on a TraceGC chromatograph equipped with a Triplus Autosampler coupled to a DeltaV Advantage IRMS through a GC-Isolink interface and a Conflo IV dilution system (all from Thermo Scientific). The chromatographic conditions were the same as those used for the GC-MS analyses, except that the GC column used (J\&W DB5, $30 \mathrm{~m}, 0.25 \mathrm{~mm}$ i.d., $0.25 \mu \mathrm{m}$ film thickness; Agilent, Palo Alto, CA, USA) was slightly different. $1 \mu \mathrm{L}$ of the sample, dissolved in toluene, was injected at least 3 times. We used a standard consisting of $1 \mu \mathrm{L}$ of a mixture of $15 n$-alkanes $\left(n-\mathrm{C}_{16}\right.$ to $\left.n-\mathrm{C}_{30}\right)$ with $\delta^{2} \mathrm{H}$ values ranging from -46.3 to $-242.3 \% \mathrm{~V}$ SMOW as determined off-line (Mixture A4, A. Schimmelmann, Indiana University, USA) to calibrate our values over the V-SMOW isotopic scale. For miliacin, $1 \mu \mathrm{L}$ of the standard mixture was co-injected with $1 \mu \mathrm{L}$ of each sample. No coelution was observed. Data were then normalized to the V-SMOW isotopic scale by using the $\delta^{2} \mathrm{H}$ values of the $n-\mathrm{C}_{25}$ and $n-\mathrm{C}_{27}$ alkanes as references (Sessions et al., 1990).

For $n$-alkanes, the standard A4 mixture was injected after every 3 samples, to calibrate reference gas prior to analyses. Then, each sample $n$-alkane $\delta^{2} \mathrm{H}$ value was normalized to the VSMOW (Vienna Standard Mean Ocean Water) isotopic scale using the reference gas $\delta^{2} \mathrm{H}$ value.

Over the period of analysis, measured $\delta^{2} \mathrm{H}$ values for the $n$-alkane A4 mixture were in good agreement with those measured off-line $\left(\mathrm{r}^{2} \geq 0.99\right)$. The overall precision for the $n$-alkane standard 
Journal Pre-proofs

Was greater tnan o\%o. I $\mu \mathrm{L}$ OI eacn sampie was injected at least tnree times, or untı tne precision was better than $6 \%$. Replicates were injected randomly in order to ensure that the reproducibility was independent of the order of the analyses. All isotopic values are expressed in \%o V-SMOW. The $\mathrm{H}_{3}{ }^{+}$factor (Sessions et al., 2001) was determined on a daily basis and was $7.26 \pm 0.17$.

\subsubsection{Statistical analyses}

Simple linear regressions were used to establish the significance of relationships between unpooled values of variables within humidity treatments (e.g., of $\delta^{2} \mathrm{H} v s . \delta^{18} \mathrm{O}$ values of water from organs affected by transpiration). Differences in the slopes and intercepts of relationships were established visually as there were not enough samples for more robust statistical comparisons via analysis of covariance. If the resulting regression equation was not significant, because the y-intercept value did not significantly differ from zero, another regression was run with a forced intercept of zero (regression through the origin).

With one $\delta^{2} \mathrm{H}$ value for each compound per hydroponic solution treatment, and thus four $\varepsilon_{\text {app }}$ values per compound in each of the two chambers, our most robust statistical options for comparing $\varepsilon$ values between compounds and humidities were non-parametric. We did not correct for possibly inflated type I error from multiple comparisons as the small sample sizes already made the likelihood of any rejection of null hypotheses very conservative. We compared $\varepsilon$ values between compounds using Wilcoxon paired-sample tests (Tables S3 and S4). Only unidirectional differences were examined (via one-tailed tests) where Wilcoxon tests were performed to compare compounds within chambers, because sample comparison numbers were too small (4 per compound) to detect overall inequalities in $\varepsilon$ value pairs (two-tailed tests). For comparisons of a compound between

humidity chambers, we performed Mann Whitney U tests of possible inequalities in $\mathcal{E}$ values within chambers (Table S5). $\varepsilon_{\text {bio }}$ values were pooled into medians per plant for non-parametric analyses. 


\section{RESULTS}

3.1. $\delta^{2} \mathrm{H}$ and $\delta^{18} \mathrm{O}$ values of water

\subsection{1. $\delta^{2} H$ and $\delta^{18} O$ values of the source water (hydroponic solutions)}

The range in $\delta^{2} \mathrm{H}$ values of water in hydroponic solution waters (HS) at $58 \%$ relative humidity $(\mathrm{RH})$ was $175 \%$, where Tank $1=-15$, Tank $2=15$, Tank $3=105$ and Tank $4=160 \%$ o (Fig. 3; Table 1). $\delta^{18} \mathrm{O}$ values were $-1.09,-2.24,-2.44$ and $-3.45 \%$. The hydroponic solution $\delta^{2} \mathrm{H}$ values at $74 \% \mathrm{RH}$ spanned a range of $223 \%$, with specific values of $-36,-10,95$, and $187 \%$ for tanks 1 through 4 , respectively. The corresponding $\delta^{18} \mathrm{O}$ values for these tanks were $-4.84,-6.58$, $6.58,-6.79 \%$ (Table 1). The slight decreases in $\delta^{18} \mathrm{O}$ values with increasing $\delta^{2} \mathrm{H}$ values at both 58 and $74 \%$ relative humidity were probably caused by the higher $\delta^{18} \mathrm{O}$ values of ${ }^{2} \mathrm{H}_{2} \mathrm{O}$ than of the tap water used for the preparation of stock solutions. The parameters of regression lines between $\delta^{18} \mathrm{O}$ and $\delta^{2} \mathrm{H}$ values for each tank and each relative humidity are given in Table $2 \mathrm{a}$.

\subsubsection{Water $\delta^{2} H$ and $\delta^{18} O$ values of non-transpiring organs}

The $\delta^{2} \mathrm{H}$ values of water in non-transpiring organs were similar to one another in a given tank and relative humidity (Table S2). At $58 \% \mathrm{RH}$, water $\delta^{2} \mathrm{H}$ values of non-transpiring organs, such as roots, first internode and other internodes, ranged from -23 to $-13 \%$ for a hydroponic solution at $-15 \%$ (Tank 1), from 14 to $18 \%$ or for hydroponic solution at $15 \%$ (Tank 2), from 104 to $111 \%$ for a hydroponic solution at 105\% (Tank 3), and from 151 to $164 \%$ o for a hydroponic solution at 160\% (Tank 4) (Figure 3 and Table 1; Table S2 contains further details). At 74\% RH, water $\delta^{2} \mathrm{H}$ values of non-transpiring organs ranged from -39 to $-35 \%$ for a hydroponic solution at - 
hydroponic solution at 95\% (Tank 3), and from 186 to 189\%o for a hydroponic solution at 187\%o (Tank 4). Furthermore, the $\delta^{2} \mathrm{H}$ values of non-transpiring organ waters (y) were nearly identical to those of their respective hydroponic solution waters (x), as evidenced by their close to $1: 1$ relationships and y-intercepts close to, or in the case of $58 \% \mathrm{RH}$, not significantly different from, 0 (Fig. 4; Table 2b).

Water $\delta^{18} \mathrm{O}$ values in non-transpiring organs were also very close to the $\delta^{18} \mathrm{O}$ values of water in their corresponding hydroponic solutions (Fig. 3; Table 1 and Table S2 contain details). At 58\% $\mathrm{RH}$, water $\delta^{18} \mathrm{O}$ values in non-transpiring organs ranged from -1.4 to $-0.8 \%$ or a hydroponic solution at $-1.1 \%$ (Tank 1 ), from -2.8 to $-2.1 \%$ for a hydroponic solution at $-2.2 \%$ (Tank 2 ), from 2.8 to $-2 \%$ for a hydroponic solution at $-2.4 \%$ (Tank 3 ), and from -3.6 to $-3 \%$ o for a hydroponic solution at $-3.4 \%$ (Tank 4$)$. At $74 \% \mathrm{RH}$, the $\delta^{18} \mathrm{O}$ values of water in non-transpiring organs ranged from -5.5 to $-4.7 \%$ for a hydroponic solution at $-4.8 \%$ (Tank 1 ), from -7 to $-6.4 \%$ o for a hydroponic solution at $-6.6 \%$ (Tank 2), from -6.7 to $-6 \%$ for a hydroponic solution at $-6.6 \%$ (Tank 3 ), and from -7 to $-6.1 \%$ for a hydroponic solution at $-6.8 \%$ (Tank 4$)$.

\subsubsection{Water $\delta^{2} H$ and $\delta^{18} \mathrm{O}$ values of transpiring organs}

The $\delta^{2} \mathrm{H}$ and $\delta^{18} \mathrm{O}$ values of water extracted from panicles were similar to, or did not differ systematically from, their respective values in leaf waters (Fig. 4; Table S2). Therefore, we pooled their $\delta$ values into a single "transpiring organs" category, comprising panicles and leaves, in further analyses (Table 1 and Fig. 4). The $\delta^{2} \mathrm{H}$ values of water extracted from transpiring organs ranged from 26 to $129 \%$ at $58 \% \mathrm{RH}$, and from -9 to $+117 \%$ at $74 \% \mathrm{RH}$ (Fig. 3; Table 1 ). At both relative humidities, the waters of transpiring organs were enriched in deuterium compared to their hydroponic solution waters when the $\delta^{2} \mathrm{H}$ values of the hydroponic solution were low (Tanks 1 and 2), but were depleted in deuterium when the $\delta^{2} \mathrm{H}$ values of the hydroponic solution were high (Tanks 3 and 4). In contrast, the $\delta^{18} \mathrm{O}$ values of the transpiring organs (TO) were always higher than their respective hydroponic solution $\delta^{18} \mathrm{O}$ values (Fig. 3; Table 1). 
transpiring organ waters $(\mathrm{y})$ to $\delta^{2} \mathrm{H}$ values of hydroponic solution waters (x) were similar for the two relative humidities (Fig. 4 and Table 2c). In contrast to what was observed for non-transpiring

organs however, the relationship of $\delta^{2} \mathrm{H}$ values of water in transpiring organs to hydroponic solution was not 1:1 but close to 0.5 at the two relative humidities (Fig. 4 and Table $2 \mathrm{c}$ ). In addition, for a given hydroponic solution $\delta^{2} \mathrm{H}$ value, the water in transpiring organs had higher $\delta^{2} \mathrm{H}$ values at $58 \%$ RH than at $74 \%$ RH (Fig. 4 and Table 2c).

For technical reasons, the vapor isotopic composition $\left(\delta_{v}\right)$ was not monitored in the chambers during experiments. Instead, we used the condensate isotopic composition $\left(\delta_{\mathrm{C}}\right.$, averaged along the experiment) to examine the water vapor in isotopic equilibrium with the condensates. In steady state conditions, the isotopic compositions of the condensates (RUBIC I: $\delta^{18} \mathrm{O}_{\mathrm{C}}=-3.5 \%$ and $\delta^{2} \mathrm{H}_{\mathrm{C}}=52 \%$ and RUBIC V: $\delta^{18} \mathrm{O}_{\mathrm{C}}=-7.0 \%$ and $\delta^{2} \mathrm{H}_{\mathrm{C}}=57 \%$ ) were about the same as the average of the isotopic compositions of the 4 hydroponic solutions (RUBIC I: $\delta^{18} \mathrm{O}_{\mathrm{HS}}=-2.3 \%$ and $\delta^{2} \mathrm{H}_{\mathrm{HS}}=$ $66 \%$; RUBIC V: $\delta^{18} \mathrm{O}_{\mathrm{HS}}=-6.2 \%$ and $\delta^{2} \mathrm{H}_{\mathrm{HS}}=59 \%$ ). Small observed differences between the measured and theoretical values were related to the mixing of isotopic transient state values (more depleted in heavy isotopes) during the first hours of the day and steady state values in the afternoon. This explains the difference between the average of the hydroponic solution and the average of the condensate isotopic compositions.

\subsubsection{Lipid $\delta^{2} H$ values}

We analysed the $\delta^{2} \mathrm{H}$ values of the $n-\mathrm{C}_{25}, n-\mathrm{C}_{27}, n-\mathrm{C}_{31}$ and $n-\mathrm{C}_{33}$ alkanes in the seeds because this is the only plant organ where miliacin is reliably abundant enough for $\delta^{2} \mathrm{H}$ value determination (e.g., Bossard et al., 2011). The $n-\mathrm{C}_{29}$ alkane was also abundant, but unfortunately co-eluted with the $5 \alpha$-cholestane used as a quantitation standard. Consequently, we were unable to obtain reliable $\delta^{2} \mathrm{H}$ values for $n-\mathrm{C}_{29}$. The data reported in Table 3 correspond to $\delta^{2} \mathrm{H}$ values of miliacin and all alkanes except $n-\mathrm{C}_{29}$ alkane, averaged per tank. 
338 values of the hydroponic solutions (Figure 4). Miliacin $\delta^{2} \mathrm{H}$ values at $58 \% \mathrm{RH}$ ranged from -77 (at $\delta^{2} \mathrm{H}_{\mathrm{HS}}=-15 \%$ ) to $-17 \%$ (at $\delta^{2} \mathrm{H}_{\mathrm{HS}}=160 \%$ ) and from $-122\left(\right.$ for $\delta^{2} \mathrm{H}_{\mathrm{HS}}=-36 \%$ ) to $-31 \%$ (for $\delta^{2} \mathrm{H}_{\mathrm{HS}}$

$=187 \%$ ) at $74 \% \mathrm{RH}$ (Figure 4; Table 3). Miliacin $\delta^{2} \mathrm{H}$ values thus spanned $60 \%$ at $58 \% \mathrm{RH}$ and $91 \%$ at $74 \% \mathrm{RH}$, over a range of $\delta^{2} \mathrm{H}_{\mathrm{HS}}$ values of 175 and $223 \%$ at the two relative humidities. $\delta^{2} \mathrm{H}$

\section{DISCUSSION}

In order to evaluate the respective impacts of source water $\delta^{2} \mathrm{H}$ values and transpiration on the $\delta^{2} \mathrm{H}$ values of $n$-alkanes and miliacin, we first discuss the impacts of water uptake and transpiration on $\delta^{2} \mathrm{H}$ and $\delta^{18} \mathrm{O}$ values of water in non-transpiring and transpiring organs. Then we examine the apparent and biosynthetic fractionations for $n$-alkanes and miliacin and compare our results to literature data. Finally, we inspect the extent to which relative humidity impacts the biosynthetic fractionation of each compound and propose an explanation for the distinct behaviour of $n$-alkanes. 


\subsubsection{Water uptake}

$\delta^{18} \mathrm{O}$ and $\delta^{2} \mathrm{H}$ values of water in non-transpiring organs (roots, first and other internodes) are close to those of their hydroponic solutions (HS; Table 1 and Fig. 3). In addition, the regression lines of $\delta^{2} \mathrm{H}$ values of non-transpiring organ waters $v s$. their corresponding hydroponic solution have nearly 1:1 slopes (58\% RH: 1.0067; 74\% RH: 1.0056; Table $2 \mathrm{~b}$ and Fig. 4) and y-intercepts that are not different from (at $58 \% \mathrm{RH}$ ), or that are close to, zero $(-0.87$ at $74 \% \mathrm{RH}$; Table $2 \mathrm{~b}$ and Fig. 4). These two results suggest that there is no discernible isotopic fractionation during water uptake and are consistent with previous studies on suberized plant tissues in which $\delta^{2} \mathrm{H}$ values of water in non-transpiring organs are the same as those of the source water (Ehleringer and Dawson, 1992; Bariac et al., 1994a,b; Terwilliger and DeNiro, 1995; Sachse et al., 2006; Gleixner and Mügler, 2007).

\subsubsection{Transpiration}

Our results suggest that the experiments at 58\% RH and at 74\% $\mathrm{RH}$ are realized under a permanent hydric regime. RUBIC I and RUBIC V are designed to provoke a permanent flow regime and isotopic steady states (hydroponic solution; $\delta_{\mathrm{HS}}$, water vapor; $\delta_{\mathrm{v}}$, water vapor transpiration; $\delta_{\mathrm{E}}$, and condensate; $\delta_{\mathrm{c}}$ ).

$$
\phi_{\mathrm{HS}}=\phi_{\mathrm{E}}=\phi_{\mathrm{C}}
$$

where $\phi_{\mathrm{HS}}$ is the flow of the source water, $\phi_{\mathrm{E}}$ is the flow of transpiration/evaporation and $\phi_{\mathrm{HS}}$ is the flow of condensates.

$\delta_{\mathrm{v}}$ is substantially constant during the day in the reactors, as are $\mathrm{RH}$ and $\delta_{\mathrm{HS}}$ for each treatment. It is therefore possible to reach an isotopic steady state in the leaf water at the end of the day. In steady state, conditions in the 3 water pools are as follows:

$$
\delta_{\mathrm{HS}} \times \phi_{\mathrm{HS}}=\delta_{\mathrm{E}} \times \phi_{\mathrm{E}}=\delta_{\mathrm{C}} \times \phi_{\mathrm{C}}
$$

So: 
$o_{H S}=o_{E}=o_{C}$

There is an isotopic equilibrium between the condensate and the vapor and between the hydroponic solution and the vapor in the reactor, with no exchange between the latter two pools. In this experiment, the plants of each treatment were supplied with differently labelled hydroponic solutions. The isotopic composition of the vapor is a mixing of vapor transpiration from plants cultivated in the four hydroponic solutions. Because of this mixing, there is no longer an isotopic equilibrium between the hydroponic solutions and the water vapor. Instead, there is an isotopic exchange between the leaf water and a vapor whose isotopic composition is very different from that encountered under natural conditions.

In contrast to non-transpiring organs, the $\delta^{2} \mathrm{H}$ values of water extracted from transpiring organs (leaves and panicles) are different from the $\delta^{2} \mathrm{H}$ values of their hydroponic solution source waters (Fig. 3). In ${ }^{2} \mathrm{H}$-depleted hydroponic solutions, the $\delta^{2} \mathrm{H}$ values of waters in transpiring organs are enriched in ${ }^{2} \mathrm{H}$ compared to the corresponding values of the hydroponic solution. In contrast, in ${ }^{2} \mathrm{H}$-enriched hydroponic solutions, the opposite trend occurs and transpiring organs are depleted in ${ }^{2} \mathrm{H}$ compared to the hydroponic solution (Fig. 3).

This shift in behaviour of water $\delta^{2} \mathrm{H}$ values in transpiring organs with respect to their source water ${ }^{2} \mathrm{H}$ enrichment is consistent with the Craig and Gordon model (1965; Eq.1) revisited by Dongmann et al. (1974) and extensively used in the literature (e.g., Bariac et al., 1989, 1990; Barbour et al., 2017). The isotopic compositions $\left(\delta^{2} \mathrm{H}\right.$ or $\left.\delta^{18} \mathrm{O}\right)$ of water vapor $\left(\delta_{\mathrm{v}}\right)$ are constant during the day in the reactors, as are the $\delta$ values of the hydroponic solution $\left(\delta_{\mathrm{HS}}\right)$ and $\mathrm{RH}$ (relative humidity). It is therefore possible to reach an isotopic steady state in the leaf water (with $\delta_{\mathrm{L}}$ ) at the end of the day.

$$
\delta_{\mathrm{L}}=\xi\left(\delta_{\mathrm{HS}}+1\right)+\mathrm{RH}\left(\delta_{\mathrm{v}}+1\right)\left(\varepsilon_{\mathrm{k}}+1\right)-1
$$

With:

$$
\xi=(1-\mathrm{RH})\left(1+\varepsilon_{\mathrm{e}}\right)\left(1+\varepsilon_{\mathrm{k}}\right)
$$

Where: 
- $\mathrm{o}_{\mathrm{L}}$ is the 1sotopic composition of leat water,

- $\mathrm{h}$ is the relative humidity of air at the leaf temperature,

- $\varepsilon_{\mathrm{e}}$ and $\varepsilon_{\mathrm{k}}$ are respectively the isotopic enrichment factor at equilibrium and the kinetic enrichment factor between liquid and vapor,

- $\delta_{\mathrm{V}}$ is the isotopic composition of the ambient water vapor,

- $\delta_{\mathrm{HS}}$ is the isotopic composition of the hydroponic solution.

Relative humidity appears to be an important factor in the isotopic variations of leaf water (Ferhi et al., 1983) via the terms " $\delta_{\mathrm{HS}}(1-\mathrm{h}) "$ and "(h $\left.\delta_{\mathrm{V}}\right) "$. When relative humidity increases in the reactor, the influence of $\delta_{\mathrm{V}}$ also increases. As mentioned by Farquhar and Cernusak (2005) and Farquhar et al. (2007), it means that at a relative humidity (h) greater than $50 \%$, more water enters the leaf from the air.

Some minor differences in water $\delta^{2} \mathrm{H}$ values are observed within a category of transpiring organs. Leaf water enrichment (both in ${ }^{2} \mathrm{H}$ and ${ }^{18} \mathrm{O}$ ) is less for lower (and senescent) than for higher leaves, which thus exhibit an intermediate enrichment between non-transpiring organs and leaves (Figure 3; further details are given in Table S2). Water extracted from panicles also shows an enrichment in both ${ }^{2} \mathrm{H}$ and ${ }^{18} \mathrm{O}$, compared to hydroponic solution waters. In most cases, the range of $\delta^{2} \mathrm{H}$ and $\delta^{18} \mathrm{O}$ values of water in panicles falls within the range found for transpiring organs (Fig. 3). This is the reason why leaves and panicles were considered together as transpiring organs in the previous sections. Panicles have glumes (Fig. 2) which are photosynthetically active and it is possible that accompanying transpiration accounts for this observed enrichment ( $\mathrm{Lu}$ and $\mathrm{Lu}, 2004$; Zhang et al., 2008). As observed for leaves, some panicle $\delta^{2} \mathrm{H}$ values were closer to those of nontranspiring organ $\delta^{2} \mathrm{H}$ values than others. This may have resulted from more introduction of water from non-transpiring panicle stems in some samples than others. Alternatively, differences in proportional inputs of more water from senescing glumes that were no longer transpiring may have produced the observed variation in $\delta^{2} \mathrm{H}$ values among the panicle samples. 
As expected, all lipids ( $n$-alkanes and miliacin) are systematically depleted in deuterium compared to their corresponding hydroponic solutions and transpiring organ waters (Figure 4; Table 3). This depletion could be due to the preferential selection of protium over deuterium during biosynthesis and may be a result of high NADPH selectivity towards deuterium (Schmidt et al., 2003; Chikaraishi et al., 2009). Apparent fractionation $\left(\varepsilon_{\text {app }}\right)$ is a measure of the difference in $\delta^{2} \mathrm{H}$ values between lipid compounds and hydroponic solution, the original source of hydrogens for organic compound synthesis in a plant. Biosynthetic fractionation $\left(\varepsilon_{\mathrm{bio}}\right)$ reflects the difference in $\delta^{2} \mathrm{H}$ values between lipid compounds and water in transpiring organs, the source of hydrogens for the production of photosynthates that will eventually be involved in the synthesis of other compounds (Gleixner and Mügler, 2007; Chikaraishi et al., 2009; Kahmen et al., 2013b).

Here, we calculate apparent fractionation as (sensu Sessions et al., 1999; Chikaraishi and Narakoa 2003):

$$
\varepsilon_{\text {app }}=1000\left[\left(\delta^{2} \mathrm{H} \text { compound }+1000\right) /\left(\delta^{2} \mathrm{H}_{\mathrm{HS}}+1000\right)-1\right]
$$

and biosynthetic fractionation as:

$$
\varepsilon_{\text {bio }}=1000\left[\left(\delta^{2} \mathrm{H} \text { compound }+1000\right) /\left(\delta^{2} \mathrm{H}_{\mathrm{TO}}+1000\right)-1\right](\text { Eq. } 3)
$$

$\mathcal{E}_{\text {bio }}$ values are medians per tank calculated from water $\delta^{2} \mathrm{H}$ values in transpiring organs (TO:

panicles and leaves; Table 3).

\subsection{1. $\mathrm{n}$-Alkanes}

As discussed above, the relationship between $\delta^{2} \mathrm{H}$ values of leaf water and hydroponic solutions (slope $\approx 0.46$ ) and between non-transpiring organs and hydroponic solutions (slope $\approx 1.0$ ) differed in a manner consistent with an explanation of transpiration influences (Fig. 4). $\boldsymbol{\varepsilon}_{\text {app }}$ values did not differ significantly between the two humidity levels for any of the $n$-alkanes ( $\mathrm{p}$ values in Table S3) and so our analyses do not take humidity into consideration. The overall (combined for 
58 and $74 \% \mathrm{RH})$ ranges of average apparent fractionations $\left(\boldsymbol{\varepsilon}_{\text {app }}\right)$ between $n$-alkanes and

463

464

465

466

hydroponic solution $\delta^{2} \mathrm{H}$ values were consistently highly variable, with a range from -209 to $-106 \%$ for $n-\mathrm{C}_{25},-213$ to $-82 \%$ for $n-\mathrm{C}_{27},-217$ to $-83 \%$ for $n-\mathrm{C}_{31}$ and -217 to $-88 \%$ or for $n-\mathrm{C}_{33}$ (Table 4 ).

The highly variable ranges of $\boldsymbol{\varepsilon}_{\text {app }}$ values are in agreement with the deviation of leaf water $\delta^{2} \mathrm{H}$ values from $\delta^{2} \mathrm{H}_{\mathrm{HS}}$ values that are thought to be caused by transpiration (as described above).

For comparison purposes with the $\boldsymbol{E}_{\text {app }}$ values given in the literature, here we only consider the most realistic water isotopic compositions for millet growing in natural conditions (with $\delta^{2} \mathrm{H}_{\mathrm{HS}}$ values at -15 at $58 \% \mathrm{RH}$ and -36 and $-10 \%$ at $74 \% \mathrm{RH})$. This gives a range of $\boldsymbol{E}_{\text {app }}$ values from 125 to $-106 \%$ for $n-\mathrm{C}_{25},-153$ to $-82 \%$ or for $n-\mathrm{C}_{27},-131$ to $-83 \%$ for $n-\mathrm{C}_{31}$ and -148 to $-88 \%$ for $n$ $\mathrm{C}_{33}$. Our $\boldsymbol{E}_{\text {app }}$ values for $n$-alkanes produced by $P$. miliaceum are consistent with ranges published in the literature for other species. In C3 plants, $\mathcal{E}_{\text {app }}$ between $n$-alkanes and growth water ranged between -230 and -22\%o (Sessions et al., 1999; Sessions, 2006, Sachse et al., 2006; 2009; 2010; Hou et al., 2007b; Feakins and Sessions 2010; Kahmen et al., 2011, 2013a;b; Garcin et al., 2012; Tipple et al., 2013; Tipple et al., 2015; Gamarra et al., 2015). For C4 plants, $\boldsymbol{\varepsilon}_{\text {app }}$ values ranged from -150 to -100\%o (Chikaraishi and Naraoka 2003; Chikaraishi et al., 2004a; Smith and Freeman, 2006; McInerney et al., 2011; Gamarra et al., 2016). To the best of our knowledge, only Smith and Freeman (2006) have determined $\boldsymbol{E}_{\text {app }}$ for a Panicum species (P. virgatum: $\boldsymbol{E}_{\text {app }}=-151 \%$ ). $\delta^{2} \mathrm{H}$ values of $n$-alkanes are related to the $\delta^{2} \mathrm{H}$ values of water in transpiring organs (Table 3 and Fig. 5). This is also illustrated by the range of $\varepsilon_{\text {bio, }}$, which is narrower than that of $\varepsilon_{\text {app }}\left(\varepsilon_{\text {bio }}=-\right.$ $151 \pm 5 \%$ for $n-\mathrm{C}_{25},-158 \pm 14 \%$ for $n-\mathrm{C}_{27},-145 \pm 14 \%$ for $n-\mathrm{C}_{31}$ and $-144 \pm 19 \%$ for $n-\mathrm{C}_{33}$; mean of all values at both relative humidities; Table 4). This is consistent with an explanation of $\delta^{2} \mathrm{H}$ 
As with the $\varepsilon_{\text {app }}$ values, our $\varepsilon_{\text {bio }}$ values of $n$-alkanes (from -163 to -130\%o) fall within the range of values reported by other authors. Feakins and Sessions (2010) reported $\varepsilon_{\text {bio }}$ of $-147 \pm 18 \%$ o for $n$-alkanes extracted from plants thriving in an entire ecosystem. For trees, $\varepsilon_{\text {bio }}$ values ranged from -120 to -170\%o (Sachse et al., 2009; Tipple et al., 2013; Kahmen et al., 2011). $\boldsymbol{\varepsilon}_{\text {bio }}$ values calculated from $n-\mathrm{C}_{29}$ and $n-\mathrm{C}_{31}$ alkanes and leaf water $\delta^{2} \mathrm{H}$ values in dicotyledonous plant species ranged from -136 to $-241 \%$ (Kahmen et al., 2013b). For C4 plants, Zhou et al. (2010) and Smith and Freeman (2006) reported $\varepsilon_{\text {bio }}$ of -180 and $-150 \%$ (the difference being attributed to temperature) and $-157 \%$, respectively. $\varepsilon_{\text {bio }}$ values calculated from Kahmen et al. (2013b) ranged between -181 and $-158 \%$ for $n-\mathrm{C}_{29}$ and $n-\mathrm{C}_{31}$ alkanes in maize. Finally, Gamarra et al. (2016) reported a mean $\varepsilon_{\text {bio }}$ of $-164 \%$ for $n$-alkanes produced by $\mathrm{C} 4$ grasses, and more specifically of $181 \%$ for Panicum virgatum. The range of $\mathcal{E}_{\text {bio }}$ for $n$-alkanes in these studies is narrower than that of $\varepsilon_{\text {app }}$ and independent of the plant type. Our study provides the first values for $n$-alkane $\varepsilon_{\text {bio }}$ in

\section{Panicum miliaceum.}

\subsubsection{Miliacin}

Like $n$-alkanes, miliacin $\delta^{2} \mathrm{H}$ values are related to $\delta^{2} \mathrm{H}$ values of water in transpiring organs with $0.725(\mathrm{RH}=58 \%)$ and $0.784(\mathrm{RH}=74 \%)$ slopes (Figure 5, Table 2$)$ and an average $\varepsilon_{\text {bio }}$ of $118 \pm 5 \%$ (Table 4). Conversely, the slopes of the miliacin $\delta^{2} \mathrm{H}$ values $v s . \delta^{2} \mathrm{H}_{\mathrm{HS}}$ values are 0.329 
$(\mathrm{RH}=58 \%)$ and $0.389(\mathrm{TH}=74 \%)$, which explains the large standard deviation $(44 \%)$ of $\varepsilon_{\text {app }}$

around an average value of $-119 \%$ (Table 4), as illustrated in Fig. 4.

Bossard et al. (2011) reported a mean $\delta^{2} \mathrm{H}$ value of $-120 \%$ for miliacin extracted from millet seeds grown in the field, with a meteoric source water of -50\%o (Millot et al., 2010). This corresponds to an $\varepsilon_{\text {app }}$ of $-73.8 \%$ which is lower than the $\varepsilon_{\text {app }}$ values we obtained (-104\%o on average at $58 \% \mathrm{RH}$ and $-133 \%$ on average at $74 \% \mathrm{RH})$.

Miliacin $\delta^{2} \mathrm{H}$ values ranged from -122 to $-18 \%$. In the literature, $\delta^{2} \mathrm{H}$ values of pentacyclic triterpenes are found in the following ranges: -171 to $-142 \%$ in Spartina alterniflora and -252 to $226 \%$ in Daucus carota (Sessions et al., 1999); -235 to $-177 \%$ in taraxerol produced by Rhizophora sp. trees in mangroves (Ladd and Sachs, 2015a); -192 to -154\%o in taraxerol produced by Rhizophora stylosa (Ladd and Sachs, 2015b) and -276 to - 185\%o (for $\beta$-amyrin), -272 to $-181 \%$ (for lupeol) and -252 to -174\% (for taraxerol) in greenhouse-grown Rhizophora mangle (Park et al., 2019).

The $\varepsilon_{\text {app }}$ of miliacin is about $-119 \%$ on average. The $\varepsilon_{\text {app }}$ of triterpenes range from - 191 to 122\%o for Spartina alterniflora (Sessions, 2006), from -226 to -150\% in Rhizophora spp. (Ladd and Sachs 2015a; 2015b), from -241 to -231\%o in Bruguiera gymnorhiza (Ladd and Sachs, 2017), and is $-150 \%$ for sedimentary triterpenols (Sauer et al., 2001), the latter identical to that reported for miliacin in Cameroon soil samples (Schwab et al., 2015). The authors reported a 20\%o increase in $\boldsymbol{\varepsilon}_{\text {app }}$ for C4 graminoid-derived pentacyclic triterpene methyl ethers (PTMEs) for a $35 \%$ decrease in $\mathrm{RH}$, in agreement with a $19 \%$ increase in $\mathcal{E}_{\text {app }}$ for miliacin with a $16 \%$ decrease in relative humidity. 
for taraxerol from Rhizophora spp. (from -229 to -148\%; Ladd and Sachs 2015a; 2015b), or for lupeol in Bruguiera gymnorhiza (from -239 to -223\%; Ladd and Sachs, 2017).

\subsubsection{Relationships between compound-specific, leaf water and $\delta^{2} H_{H S}$ values}

As explained earlier, the $\delta^{2} \mathrm{H}$ values of miliacin and $n$-alkanes correlate with leaf water $\delta^{2} \mathrm{H}$

\subsubsection{Differences in $\varepsilon_{\text {bio }}$ between miliacin and $\mathrm{n}$-alkanes}

The overall average $\varepsilon_{\text {bio }}$ value was $-118 \pm 5 \%$ for miliacin, whereas it reached $-151 \pm 7$, -

$158 \pm 14,-145 \pm 14$ and $-144 \pm 19 \%$ for the $n-\mathrm{C}_{25}, n-\mathrm{C}_{27}, n-\mathrm{C}_{31}$ and $n-\mathrm{C}_{33}$ alkanes, respectively

(Table 4). This constitutes a significant (Table S4 shows Wilcoxon paired sample tests between the

$\varepsilon_{\text {bio }}$ values of each compound) enrichment of this C-3 oxygenated pentacyclic triterpene compared to $n$-alkanes. This is in contrast to previous studies in which pentacyclic triterpenes were depleted 
and Sachs, 2015a), compared to $n$-alkanes. This depletion is the same as that observed for sterols compared to $n$-alkyl lipids (Sessions et al., 1999; Zhou et al., 2016; Chikaraishi et al., 2004a; 2004b) and is classically attributed to the distinct metabolic pathways leading to these compounds, and the source of their hydrogen atoms. $n$-Alkanes are produced via the acetogenic pathway from palmitic acid produced in the chloroplast and then by the decarboxylation and elongation that occur in the cytosol. Their hydrogen atoms are thought to derive from intracellular water $(50 \%)$, from carbohydrate precursors (25\%) and from NADPH (25\%; Sachse et al., 2012). C-3 oxygenated pentacyclic triterpenes, as well as tetracyclic triterpenes (sterols), are produced in the cytosol via the mevalonic acid pathway (MVA; Sessions et al., 1999; Sessions, 2006; Chikaraishi et al., 2009; Zhou et al., 2011) from isopentenyl diphosphate, a precursor that is produced in both the plastid and the cytosol, with uncertainties on how much can be transported through the plastid membrane. These separate pathways not only involve distinct enzymatic processes but also different pools of water (in the cytosol and in the plastid) with which C-bound hydrogen atoms can be exchanged. They also involve different pools of NADPH produced through distinct processes and with distinct isotopic values (Cormier et al., 2018) that can significantly modify the isotopic composition of the final product; for example, during hydrogenation and dehydrogenation (Chikaraishi et al., 2009). According to Sachse et al. (2012), the ${ }^{2} \mathrm{H}$-depletion of isoprenoid lipids produced through the MVA pathway compared to $n$-alkyl lipids is due to hydrogen atoms transferred from NADPH to terpene intermediates during the synthesis of mevalonate.

Our data show the reverse, with miliacin being enriched compared to $n$-alkanes. This pattern has already been encountered in Spartina alterniflora (a C4 Poaceae), where there was either no difference (Sessions et al., 1999), or a $20 \%$ enrichment (Sessions, 2006) of pentacyclic triterpenes compared to $n$-alkanes. Hence, an enrichment of pentacyclic triterpenes compared to $n$-alkanes could be specific to $\mathrm{C} 4$ grasses, probably related to the compartmentation of photosynthesis in $\mathrm{C} 4$ plants into mesophyll and bundle sheath cells. Water in bundle sheath cells at the base of C4 
Joumal Pre-proofs

grasses leaves is a mix between xyıem (non-evaporated water) and leai water (submittea to

evaporation). Organic compounds produced in bundle sheath cells are hence ${ }^{2} \mathrm{H}$-depleted compared to compounds produced in the rest of the leaves, because they derive from waters less subjected to evaporation (Zhou et al., 2016; Gamara et al., 2016). In our case, the ${ }^{2} \mathrm{H}$-enrichment of miliacin compared to $n$-alkanes could result from the preferential synthesis of $n$-alkanes in basal cells, whereas miliacin could be produced in mesophyll cells. This hypothesis is contradicted by Chikaraishi et al. (2004) who reported depleted sterols compared to $n$-alkanes in C4 grasses and, more clearly, by Zhou et al. (2016) who reported an $\varepsilon_{\text {bio }}$ of $-155 \%$ for $n$-alkanes and of $-200 \%$ for sterols in Panicum coloratum. Therefore, it is unclear whether the ${ }^{2} \mathrm{H}$-enrichment observed for miliacin compared to $n$-alkanes results from a specificity of miliacin synthesis, or a peculiarity of $P$. miliaceum.

Specific attention should be paid to the plant location from which we extracted lipids. We observed a good correlation between the $\delta^{2} \mathrm{H}$ values of lipids and water in transpiring organs (leaves and panicles) but this relationship could mask more complex mechanisms. It is unclear whether, in P. miliaceum, lipids can be directly photosynthesized in seeds; i.e., whether hydrogen atoms could originate from seed water, this water possibly having a distinct isotopic composition compared to that of leaves (Sanchez-Bragado et al., 2019). Alternatively, lipids in seeds could be synthesised from intermediates that were formed during pre-anthesis by photosynthesis in leaves, and then translocated to seeds during grain-filling, with additional fractionation. Although such heterotrophy is also observed in leaves, it could be more prevalent for lipids produced in seeds, and could be a more important shaper of lipid $\delta^{2} \mathrm{H}$ values than the organ water isotopic composition. In addition, lipids could also be transferred directly from leaves to seeds in late stages of maturation, as suggested for mustard (Mukherjee, 1983). There is currently no information available for the time at which these processes occur in P. miliaceum. The extent to which all these factors more or less affect $\delta^{2} \mathrm{H}$ values of short chain $n$-alkanes, long chain $n$-alkanes and miliacin, remains to be elucidated in order to better understand the significance of $\varepsilon_{\text {bio }}$ values. 


\subsection{Impact of relative humidity}

\subsubsection{Impact of relative humidity on leaf water $\delta^{2} H$ values}

The impact of transpiration is visible from the data shown in Figure 6 with $\delta^{2} \mathrm{H}$ values of water in transpiring organs systematically $\sim 29 \%$ higher at $58 \%$ than at $74 \%$ relative humidity (calculated from the intercepts of respective regression lines displayed in Table 2). Eq. (1) shows that, depending on the isotopic compositions of the hydroponic solutions, there is a theoretical maximum difference of $6.5 \%$ for ${ }^{18} \mathrm{O}$ and $35 \%$ for ${ }^{2} \mathrm{H}$, when passing from $58 \%$ to $74 \%$ relative humidity. This supports the idea that leaf water $\delta^{2} \mathrm{H}$ values are not only influenced by the $\delta^{2} \mathrm{H}_{\mathrm{HS}}$ values, but also by relative humidity. This illustrates the impact of relative humidity on water flux control in stomata (Manzoni et al., 2013), attested by increasing the weight of the term " $\delta_{\mathrm{HS}}(1-\mathrm{h})^{\text {" }}$ and decreasing the weight of the term " $\mathrm{h}\left(\delta_{\mathrm{v}}-\varepsilon_{\mathrm{k}}\right)$ " with decreasing humidity in Eq. (1) (Craig and Gordon, 1965).

\subsubsection{Impact of relative humidity on $\boldsymbol{\varepsilon}_{\text {bio }}$ values}

As described above, the first parameter that controls miliacin and $n$-alkane $\delta^{2} \mathrm{H}$ values is leaf water $\delta^{2} \mathrm{H}$. For a given relative humidity, $\boldsymbol{\varepsilon}_{\text {bio }}$ values of each compound are rather homogeneous, regardless of the $\delta^{2} \mathrm{H}_{\mathrm{HS}}$ values. This result is consistent with some previous studies (i.e., Hou et al., 2007b; Chikaraishi et al., 2009; Kahmen et al., 2013a). Sachse et al. (2010) reported that lipid $\delta^{2} H$ values are mainly controlled by the leaf water $\delta^{2} \mathrm{H}$ value which, in turn, is influenced by the $\delta^{2} \mathrm{H}_{\mathrm{HS}}$ value. However, the leaf water enrichment compared to the hydroponic solution is mainly due to the humidity that partly controls transpiration (Kahmen et al., 2013a,b).

For miliacin, the difference in $\varepsilon_{\text {bio }}$ between 58 (from - 124 to -112\%o) and 74\% RH (from - 
alkane $\varepsilon_{\text {bio }}$ values with respect to RH are noted. If confirmed, this could provide clues about

623

624

variations in the respective impacts of source water $\delta^{2} \mathrm{H}$ values and relative humidity on the $\delta^{2} \mathrm{H}$

values of biochemicals. $\varepsilon_{\text {bio }}$ values for the $n-\mathrm{C}_{25}$ alkane are similar at both relative humidities (from -161 to $-142 \%$ at $58 \%$ and from -163 to $-146 \%$ at $74 \mathrm{H} \mathrm{RH}$; Table 4; Fig. 7; Mann Whitney U test statistics are summarised in Table S5). The same applies to $n-\mathrm{C}_{27}$, with no significant difference in $\varepsilon_{\text {bio }}$ values between $58 \%$ RH (from -169 to $-130 \%$ ) and $74 \%$ RH (from -175 to $-149 \%$ ). For longer chain $n$-alkanes ( $n$ - $\mathrm{C}_{31}$ and $\left.n-\mathrm{C}_{33}\right)$, the difference in $\boldsymbol{E}_{\text {bio }}$ between the two relative humidity levels, although small, is significant at $\mathrm{p}=0.03$ (Table 4 and Fig. 7; Mann Whitney U test statistics are provided in Table S5). There is more biosynthetic fractionation at $74 \% \mathrm{RH}$, compared to $58 \% \mathrm{RH}$, for $n-\mathrm{C}_{31}$ (from -166 to $-150 \%$ andfrom -145 to $-131 \%$, respectively) and for $n-\mathrm{C}_{33}$ (from -184 to $142 \%$ and from -136 to $-122 \%$ ). This constitutes a 23 (for $n-\mathrm{C}_{31}$ ) and a $28 \%$ (for $n-\mathrm{C}_{33}$ ) additional fractionation of hydrogen isotopes for a $16 \%$ increase in RH. Such a distinct behaviour of $n$-alkane biosynthetic fractionation depending on carbon chain-length was reported by Kahmen et al. (2013b). In their case, less fractionation was observed for the $n-C_{31}$ alkane under drier conditions for Populus balsamifera and Helianthus annus. The reverse was observed for Zea mays and

Triticum aestivum (Figure 7). There is as yet no clear pattern of $\varepsilon_{\text {bio }}$ changes with relative humidity.

The small difference in behaviour of the $\varepsilon_{\text {bio }}$ values of $n$-alkanes towards humidity suggested by our results could be related to different proportions of hydrogen atoms derived from the chloroplast and from the cytosol, depending on chain length. During $n$-alkane elongation beyond 16 carbon atoms, they integrate a larger proportion of cytoplasmic hydrogen atoms (derived from water or from NADPH) compared to chloroplastic hydrogen atoms. The contribution of hydrogens originating from the chloroplast thus decreases with increasing chain length. As humidity increases, longer 
cnain $n$-alkanes may integrate nyarogen atoms tnat are more ${ }^{2} H$-depıeted rrom water in tne cytosol, but not from cytosolic NADPH that is considered ${ }^{2} \mathrm{H}$-enriched compared to plastidic NADPH (Cormier et al., 2018). This would imply a preferential input of water $\mathrm{H}$ atoms compared to NADPH during $n$-alkane elongation in the cytosol, for which we have no explanation. Conversely, because the synthesis of miliacin only occurs in the cytosol (except for a potential contribution of the isopentenyl diphosphate precursor from the plastid; Hemmerlin et al., 2012), $\varepsilon_{\text {bio }}$ does not appear to be affected by relative humidity. The small relative humidity difference between the two chambers $(16 \%)$, when compared to similar studies (34\% for Tipple et al., 2015; 35.2\% for Kahmen et al., 2013b) may have been insufficient to reveal differences in miliacin $\boldsymbol{\varepsilon}_{\text {bio }}$ values.

Our results could also have been affected by the specific experimental setting we used, implying transpiration of millet plants growing over a very large range of $\delta^{2} \mathrm{H}$ values of the hydroponic solution in the same chamber. Through the backflow of water vapor in the leaf, this may have modified the expected isotopic composition of leaf water and could have masked or altered the impacts of relative humidity.

These findings indicate that studies to more precisely discern the isotopic contributions of source water $\delta^{2} \mathrm{H}$ values and to back-calculate relative humidity are now needed to maximize the rigor of the palaeoclimatic interpretation of $\delta^{2} \mathrm{H}$ values from sedimentary biomarkers. Evaluating the extent to which minute differences in $\delta^{2} \mathrm{H}$ values of $n$-alkanes in a single $\mathrm{C} 4$ plant may reflect relative humidity is a promising study strategy. Our results also suggest that the relationships between the $\delta^{2} \mathrm{H}$ values of lipids and climate factors should be compared between leaves and seeds, especially as the latter can be an important source of sedimentary biomarkers.

\section{CONCLUSIONS}

The quality of interpretation of compound-specific isotope analysis in sedimentary archives for paleoclimatic studies, and the potential to obtain quantitative estimates of variables that define 
Journal Pre-proofs

tne nyarological cycie, are contungent upon our understanaing of the main parameters tnat aIIect these $\delta^{2} \mathrm{H}$ values. Our contribution was conducted on Panicum miliaceum plants cultivated under controlled conditions over hydroponic solutions of varying $\delta^{2} \mathrm{H}$ values, and under two relative humidity levels.

$\delta^{2} \mathrm{H}$ values of $n$-alkanes and miliacin showed a strong correlation with leaf water $\delta^{2} \mathrm{H}$ values as indicated by relatively constant biosynthetic fractionation when compared to apparent fractionations. Our results thus confirm that leaf water $\delta^{2} \mathrm{H}$ values (which integrate source water $\delta^{2} \mathrm{H}$ values and transpiration) are the main control that shapes the $\delta^{2} \mathrm{H}$ values of biochemicals. The difference in biosynthetic fractionations between two humidity levels is non-significant for miliacin, $n-\mathrm{C}_{25}$ and $n-\mathrm{C}_{27}$ alkanes, but becomes significant for longer chain $n$-alkanes. We suspect that the respective impacts of humidity and source water $\delta^{2} \mathrm{H}$ values could be discriminated by comparing $\delta^{2} \mathrm{H}$ values of compounds made for hydrogen atoms originating from distinct compartments and sources within photosynthetic cells. Nonetheless, our results could also be affected both by the specific experimental design, which may have muted any relationship between lipid $\delta^{2} \mathrm{H}$ values and relative humidity, and by the organ from which lipids were extracted, since there is currently a lack of knowledge on the source of their hydrogen atoms and the timing of their synthesis. The hypotheses drawn here should thus be confirmed by additional experiments.

\section{ACKNOWLEDGMENTS}

The authors wish to thank S. Feakins (as an Associate Editor for a first version of the manuscript, and as a reviewer), N. Ladd and three anonymous reviewers for their impressive work and constructive comments on an earlier version of this manuscript. This study was part of the PalHydroMil Project, supported by an Agence Nationale de la Recherche grant (ANR-2010JCJC607-1). N. Bossard received a PhD grant provided by the Ministère de la Recherche et de l'Enseignement Supérieur (Action Thématique Prioritaire, 2009-2012). V. J. Terwilliger was a 
696 Studies). E. Rowley-Jolivet is acknowledged for English language editing of the manuscript. 
KEFEKEIVLES

Allison, G.B., Leaney, F.W., 1982. Estimation of isotopic exchange parameters, using constant-feed pans. Journal of Hydrology 55, 151-161.

Araguás-Araguás, L., Rozanski, K., Gonfiantini, R., Louvat, D., 1995. Isotope effects accompanying vacuum extraction of soil water for stable isotope analyses. Journal of Hydrology 168, 159-171.

Bai, Y., Fang, X., Gleixner, G., Mügler, I., 2011. Effect of precipitation regime on $\delta^{2} \mathrm{H}$ values of soil n-alkanes from elevation gradients - Implications for the study of paleo-elevation. Organic Geochemistry 42, 838-845.

Barbour, M.M., Farquhar, G.D., Buckley, T.N., 2017. Leaf water stable isotopes and water transport outside the xylem. Plant Cell \& Environment. 40, 914-92.

Bariac, T., Rambal, S.A., Jusserand, C., Berger A., 1989. Evaluating water flux of field-grown alfalfa from diurnal observations of natural isotope concentrations, energy budget and ecophysiological parameters. Agricultural and Forest Meteorology 48, 263-283.

Bariac, T., Jusserand, C., Mariotti, A., 1990. Evolution spatio-temporelle de la composition isotopique de l'eau dans le continuum sol-plante-atmosphère. Geochimica et Cosmochimica Acta 54, 13-424.

Bariac T., Gonzalez-Dunia J., Katerji N., Béthenod O., Bertolini J.M., Mariotti, A. (1994a) Spatial variation of the isotopic composition of water $\left({ }^{18} \mathrm{O},{ }^{2} \mathrm{H}\right)$ in the soil-plant-atmosphere system, 2. Assesment under field conditions. Chemical Geology 115, 317-333.

Bariac, T., Gonzalez-Dunia, J., Tardieu, F., Tessier, D., Mariotti, A., 1994b. Spatial variation of the isotopic composition of water $\left({ }^{18} \mathrm{O},{ }^{2} \mathrm{H}\right)$ in organs of aerophytic plants: 1 . Assessment under laboratory conditions. Chemical Geology 115, 307-315.

Bossard, N., Jacob, J., Le Milbeau, C., Lallier-Verges, E., Terwilliger, V.J., Boscardin R., 2011. Variation in $\delta \mathrm{D}$ values of a single, species-specific molecular biomarker: a study of miliacin 
Mass Spectrometry 25, 1-9.

Bossard, N., Jacob, J., Le Milbeau, C., Sauze, J., Terwilliger, V.J., Poissonnier, B., Verges, E., 2013. Distribution of miliacin (olean-18-en-3 $\beta$-ol methyl ether) and related compounds in broomcorn millet (Panicum miliaceum) and other reputed sources: Implications for the use of sedimentary miliacin as a tracer of millet. Organic Geochemistry 63, 48-55.

Bossard, N., 2013. Pertinence et calibration d'un nouveau marqueur paléohydrologique : Le rapport isotopique de l'hydrogène mesuré sur la miliacine. Ph.D. thesis, Université d'Orléans, Orléans, France, 187 pp.

Chikaraishi, Y., Narakoa, H., 2003. Compound-specific $\delta \mathrm{D}-\delta^{13} \mathrm{C}$ analyses of $n$-alkanes extracted from terrestrial and aquatic plants. Phytochemistry 63, 361-371.

Chikaraishi, Y., Naraoka, H., Poulson, S.R., 2004. Hydrogen and carbon isotopic fractionations of lipid biosynthesis among terrestrial (C3, C4 and CAM) and aquatic plants. Phytochemistry $65,1369-1381$.

Chikaraishi, Y., Tanaka, R., Tanaka, A., Ohkouchi, N., 2009. Fractionation of hydrogen isotopes during phytol biosynthesis. Organic Geochemistry 40, 569-573.

Cormier, M.A., Werner, R.A., Sauer, P.E. Gröcke, D.R., Leuenberger, M.C., Wieloch, T., Schleucher, J., Kahmen A., 2018. ${ }^{2} \mathrm{H}$-fractionations during the biosynthesis of carbohydrates and lipids imprint a metabolic signal on the $\delta^{2} \mathrm{H}$ values of plant organic compounds. New Phytologist 218, 479-491.

Craig, H., 1961. Isotopic variations in meteoric waters. Science 133, 1702-1703.

Craig, H., Gordon, L.I., 1965. Deuterium and oxygen 18 variations in the ocean and the marine atmosphere, In: Tongiorgi, E. (Eds.), Stable Isotopes in Oceanographic Studies and Paleotemperatures. Consiglio nazionale delle richerche, Laboratorio de geologia nucleare, Spoleto, Italy. pp. 9-131.

Dansgaard, W., 1964. Stable isotopes in precipitation. Tellus 16, 436-468. 
Dieienaori, A.F., Freeman, K.H., wing, S.L., Uranam H.V., LU11. Proauction or $n$-alkyı ıpıas in living plants and implications for the geologic past. Geochimica et Cosmochimica Acta 75, $7472-7485$.

Diefendorf, A.F., Freimuth E.J., 2017. Extracting the most from terrestrial plant-derived $n$-alkyl lipids and their carbon isotopes from the sedimentary record: A review. Organic Geochemistry 103, 1-21.

Dongman, G., Nürnberg, H.W., Förstel, H., Wagener, K., 1974. On the enrichment of $\mathrm{H}_{2}{ }^{18} \mathrm{O}$ in the leaves of transpiring plants. Radiation and Environmental Biophysics 11, 41-52.

Douglas, P.M.J., Pagani, M., Brenner, M., Hodell, D.A., Curtis, J. H., 2012. Aridity and vegetation composition are important determinants of leaf-wax $\delta^{2} \mathrm{H}$ values in southeastern Mexico and Central America. Geochimica et Cosmochimica Acta 97, 24-45.

Eglinton, G., Hamilton, R.J., 1967. Leaf epicuticular waxes. Science 156, 1322-1335.

Ehleringer, J.R., Dawson, T. E., 1992. Water uptake by plants: perspectives from stable isotope composition. Plant, Cell \& Environment 15, 1073-1082.

Estep, M., Hoering, T., 1980. Biogeochemistry of the stable hydrogen isotopes. Geochimica et Cosmochimica Acta 44, 1197-1206.

Farris, R., Strain, B., 1978. The effect of water-stress on leaf $\mathrm{H}_{2}{ }^{18} \mathrm{O}$ enrichment. Radiation and Environmental Biophysics 15,167-202.

Farquhar, G.D., Cernusak, L.A., 2005. On the isotopic composition of leaf water in the non-steady state. Functional Plant Biology 32, 293-303.

Farquhar, G.D., Cernusak, L.A., Barnes, B., 2007. Heavy water fractionation during transpiration. Plant Physiology 143, 11-18.

Feakins, S.J., Sessions, A.L., 2010. Controls on the D/H ratios of plant leaf waxes in an arid ecosystem. Geochimica et Cosmochimica Acta 74, 2128-2141. 
Journal Pre-proofs

Fernı, A., Barıac, 1., Jusserana, C., Letome, K., 19ð3. An integratea metnod ior isotopic anaıysis oI oxygen from organic compounds, air water vapor and leaf water. The International Journal of Applied Radiation and Isotopes 34, 1451-1457.

Gamarra, B., Sachse, D., Kahmen, A., 2016. Effects of leaf water evaporative ${ }^{2} \mathrm{H}$-enrichment and biosynthetic fractionation on leaf wax $n$-alkane $\delta^{2} \mathrm{H}$ values in $\mathrm{C} 3$ and $\mathrm{C} 4$ grasses. Plant, Cell \& Environment 39, 2390-2403.

Gao, L., Edwards, E.J., Zeng, Y., Huang, Y., 2014. Major evolutionary trends in hydrogen isotope fractionation of vascular plant leaf waxes. PLOS ONE 9, e112610.

Garcin, Y., Schwab, V.F., Gleixner, G., Kahmen, A., Todou, G., Séné, O., Onana, J.M., Achoundong, G., Sachse, D., 2012. Hydrogen isotope ratios of lacustrine sedimentary nalkanes as proxies of tropical African hydrology: Insights from a calibration transect across Cameroon. Geochimica et Cosmochimica Acta 79, 106-126.

Gleixner, G., Mügler, I., 2007. Compound-specific hydrogen isotope ratios of biomarkers: tracing climatic changes in the past, In: Dawson, T.E., Siegwolf, R.T.W. (Eds.), Stable isotopes as indicators of ecological change. Oxford Academic Press, Oxford, pp. 249-266.

Gonfiantini, R., Gratsiu, S., Tongiorgi, E., 1965. Oxygen isotopic composition of water in leaves. In Isotopes and Radiation in Soil Plant Nutrition Studies. IAEA, Vienna. pp. 405-410.

Hemmerlin, A., Harwood, J.L., Bach, T.J., 2012. A raison d'être for two distinct pathways in the early steps of plant isoprenoid biosynthesis? Progress in Lipid Research 51, 95-148.

Hou, J., D'Andrea, W.J., Mac Donald, D., Huang, Y., 2007a. Evidence for water use efficiency as an important factor in determining the $\delta^{2} \mathrm{H}$ values of tree leaf waxes. Organic Geochemistry $38,1251-1255$.

Hou, J., D’Andrea, W.J., McDonald, D., Huang, Y., 2007b. Hydrogen isotopic variability in leaf waxes among terrestrial and aquatic plants around Blood Pond, Massachussetts (USA). Organic Geochemistry 38, 977-984. 
Joumal Pre-proofs

Huang, Y., snuman, B., Wang, Y., Weob, 1 ., LUUL. Hyarogen isotope ratios or paimitic acia in lacustrine sediments record late Quaternary climate variations. Geology 30, 1103-1106.

Jacob, J., Disnar, J.-R., Boussafir, M., Spadano Albuquerque, A.L., Sifeddine, A., Turcq, B., 2005. Pentacyclic triterpene methyl ethers in recent lacustrine sediments (Lagoa do Caço, Brazil). Organic Geochemistry 36, 449-461.

Jacob, J., Disnar, J.R., Arnaud, F., Chapron, E., Debret, M., Lallier-Vergès, E., Desmet, M., RevelRolland, M., 2008a. Millet cultivation history in the French Alps as evidenced by a sedimentary molecule. Journal of Archaeological Science 35, 814-820.

Jacob, J., Disnar, J.R., Bardoux, G., 2008b. Carbon isotope evidence for sedimentary miliacin as a tracer of Panicum miliaceum (broomcorn millet) in the sediments of Lake le Bourget (French Alps). Organic Geochemistry 39, 1077-1080.

Jacob, J., Disnar, J.R., Arnaud, F., Gauthier, E., Billaud, Y., Chapron, E., Bardoux, G., 2009. Impacts of new agricultural practices on soil erosion during the Bronze Age in French Prealps. The Holocene 19, 241-249.

Jia, G., Wei, K., Chen, F., Peng, P., 2008. Soil $n$-alkane $\delta^{2} H$ vs. altitude gradients along Mount Gongga, China. Geochimica et Cosmochimica Acta 72, 5165-5174.

Kahmen, A., Dawson, T.E., Vieth, A., Sachse, D., 2011. Leaf wax $n$-alkane $\delta^{2} H$ values are determined early in the ontogeny of Populus trichocarpa leaves when grown under controlled environmental conditions. Plant, Cell \& Environment 34, 1639-1651.

Kahmen, A., Hoffmann, B., Schefuss, E., Arndt, S.K., Cernusak, L.A., West, J.B., Sachse, D., 2013a. Leaf water deuterium enrichment shapes leaf wax $n$-alkane $\delta^{2} \mathrm{H}$ values of angiosperm plants II: Observational evidence and global implications. Geochimica et Cosmochimica Acta $111,50-63$.

Kahmen, A., Schefuss, E., Sachse, D., 2013b. Leaf water deuterium enrichment shapes leaf wax $n$ alkane $\delta^{2} \mathrm{H}$ values of angiosperm plants I: Experimental evidence and mechanistic insights. Geochimica et Cosmochimica Acta 11, 39-49. 
Ladd, N.S., Sachs, J.P., 2015b. Hydrogen isotope response to changing salinity and rainfall in Australian mangroves. Plant, Cell \& Environment 38, 2674-2687.

Ladd, S.N., Sachs, J.P., 2017. ${ }^{2} \mathrm{H} /{ }^{1} \mathrm{H}$ fractionation in lipids of the mangrove Bruguiera gymnorhiza increases with salinity in marine lakes of Palau. Geochimica et Cosmochimica Acta 204, 300312.

Liu, W., Yang, H., 2008. Multiple controls for the variability of hydrogen isotopic compositions in higher plant $n$-alkanes from modern ecosystems. Global Change Biology 14, 2166-2177.

Longchamp, M., Castrec-Rouelle, M., Biron, P., Bariac, T., 2015. Variations in the accumulation, localization and rate of metabolization of selenium in mature Zea mays plants supplied with selenite or selenate. Food Chemistry 182, 128-135.

Lu, H., Zhang, J., Wu, N., Liu, K.B., Xu, D., Li, Q., 2009. Phytoliths analysis for the discrimination of foxtail millet (Setaria italica) and common millet (Panicum miliaceum). PLoS ONE 4, e4448.

Lu, Q., Lu, C., 2004. Photosynthetic pigment composition and photosystem II photochemistry of wheat ears. Plant Physiology and Biochemistry 42, 395-402.

Manzoni, S., Vico, G., Katul, G., Porporato, A., 2013. Biological constraints on water transport in the soil-plant-atmosphere system. Advances in Water Resources 51, 292-304.

McInerney, F.A., Helliker, B.R., Freeman, K.H., 2011. Hydrogen isotope ratios of leaf wax $n$ alkanes in grasses are insensitive to transpiration. Geochimica et Cosmochimica Acta 75, 541554.

Millot, R., Petelet-Giraud, E., Guerrot, C., Négrel, P., 2010. Multi-isotopic composition $\left(\delta^{7} \mathrm{Li}-\delta^{11} \mathrm{~B}-\right.$ $\left.\delta \mathrm{D}-\delta^{18} \mathrm{O}\right)$ of rain waters in France: Origin and spatio-temporal characterization. Applied Geochemistry 25, 1510-1524. 

934.

Park, W.J., Ladd, N.S., Sachs, J.P., 2019. Hydrogen and carbon isotope responses to salinity in greenhouse-cultivated mangroves. Organic Geochemistry 132, 23-36.

Polissar, P.J., Freeman, K.H., 2010. Effects of aridity and vegetation on plant-wax $\delta^{2} \mathrm{H}$ in modern lake sediments. Geochimica et Cosmochimica Acta 74, 5785-5797.

Rothfuss, Y., Biron, P., Braud, I., Canale, L., Durand, J.L., Gaudet, J.P., Richard, P., Vauclin, M., Bariac, T., 2010. Partitioning evapotranspiration fluxes into soil evaporation and plant transpiration using water stable isotopes under controlled conditions. Hydrological Processes 24, 3177-3194.

Sachse, D., Radke, J., Gleixner, G., 2004. Hydrogen isotope ratios of recent lacustrine sedimentary n-alkanes record modern climate variability. Geochimica et Cosmochimica Acta 68, 48774889.

Sachse, D., Radke, J., Gleixner, G., 2006. $\delta$ D values of individual $n$-alkanes from terrestrial plants along a climatic gradient - Implications for the sedimentary biomarker record. Organic Geochemistry 37, 469-483.

Sachse, D., Kahmen, A., Gleixner, G., 2009. Significant seasonal variation in the hydrogen isotopic composition of leaf-wax lipids for two deciduous tree ecosystems (Fagus sylvatica and Acer pseudoplatanus). Organic Geochemistry 40, 732-742.

Sachse, D., Gleixner, G., Wilkes, H., Kahmen, A., 2010. Leaf wax $n$-alkane $\delta^{2} H$ values of fieldgrown barley reflect leaf water $\delta^{2} \mathrm{H}$ values at the time of leaf formation. Geochimica et Cosmochimica Acta 74, 6741-6750.

Sachse, D., Billault, I., Bowen, G.J., Chikaraishi, Y., Dawson, T.E., Feakins, S.J., Freeman, K.H., Magill, C.R., McInerney, F.A., van der Meer, M.T.J., Polissar, P., Robins, R., Sachs, J.P., Schmidt, H.-L., Sessions, A.L., White, J.W.C., West, J.B., Kahmen, A., 2012. Molecular 
Journal Pre-proofs

paleonyaroıogy: interpretıng tne nyarogen-1sotopic composition oi ıpıd biomarkers irom photosynthetic organisms. Annual Reviews of Earth and Planetary Sciences 40, 221-249.

Sanchez-Bragado, R., Serret, M.D., Marimon, R.M., Bort, J. and Araus, J.L., 2019. The hydrogen isotope composition $\delta 2 \mathrm{H}$ reflects plant performance. Plant Physiology 180, 793-812.

Sauer, P.E., Eglinton, T.I., Hayes, J.M., Schiemmelmann, A., Sessions, A.L., 2001. Compoundspecific $\mathrm{D} / \mathrm{H}$ ratios of lipid biomarkers from sediments as a proxy for environmental and climatic conditions. Geochimica et Cosmochimica Acta 65, 213-222.

Schmidt, H.-L., Werner, R.A., Eisenreich, W., 2003. Systematics of ${ }^{2} \mathrm{H}$ patterns in natural compounds and its importance for the elucidation of biosynthetic pathways. Phytochemical Reviews 2, 61-85.

Schwab, V.F., Garcin, Y., Sachse, D., Todou, G., Séné, O., Onana, J.-M., Achoundong, G., Gleixner, G., 2015. Effect of aridity on $\delta^{13} \mathrm{C}$ and $\delta \mathrm{D}$ values of $\mathrm{C} 3$ plant- and $\mathrm{C} 4$ graminoidderived leaf wax lipids from soils along an environmental gradient in Cameroon (Western Central Africa). Organic Geochemistry 78, 99-109.

Sessions, A.L., Burgoyne, T.W., Schimmelmann, A., Hayes, J.M., 1999. Fractionation of hydrogen isotopes in lipid biosynthesis. Organic Geochemistry 30, 1193-1200.

Sessions, A.L., Burgiyne, T.W., Hayes, J.M., 2001. Correction of $\mathrm{H}^{+}$contributions in hydrogen isotope ratio monitoring mass spectrometry. Analytical Chemistry 73, 192-199.

Sessions, A.L., 2006. Seasonal changes in D/H fractionation accompanying lipid biosynthesis in Spartina alterniflora. Geochimica et Cosmochimica Acta 70, 2153-2162.

Sessions, A.L., 2016. Factors controlling the deuterium contents of sedimentary hydrocarbons. Organic Geochemistry 96, 43-64.

Smith, F.A., Freeman, K.H., 2006. Influence of physiology and climate $\delta \mathrm{D}$ of leaf wax $n$-alkanes from C3 and C4 grasses. Geochimica et Cosmochimica Acta 70, 1172-1187. 
Journal Pre-proofs

I erwilliger, v.J., Deiviro, IVI.J., 19yJ. Hyarogen isotope Iractionation in wood-producing avocado seedlings: Biological constraints to paleoclimatic interpretations of $\delta \mathrm{D}$ values in tree ring cellulose nitrate. Geochimica et Cosmochimica Acta 59, 5199-5207.

Terwilliger, V.J., Jacob, J., 2013. Introduction: Hydrogen isotopes as environmental recorders. Geochimica et Cosmochimica Acta 111, 1-4.

Tipple, B.J., Pagani, M., 2013. Environmental control on eastern broadleaf forest species' leaf wax distributions and D/H ratios. Geochimica et Cosmochimica Acta 111, 64-77.

Tipple, B.J., Berke, M.A., Hambach, B., Roden, J.S., Ehleringer, J.R., 2015. Predicting leaf wax $n$ alkane ${ }^{2} \mathrm{H} /{ }^{1} \mathrm{H}$ ratios: controlled water source and humidity experiments with hydroponically grown trees confirm predictions of Craig-Gordon model. Plant, Cell \& Environment 38, 1035-1047.

Yakir, D., 1992. Water compartmentation in plant tissue: isotopic evidence, In: Somero, S.G.N., Osmond, C.B., Bolis, C.L. (Eds.), Water and Life. Springer-Verlag, Berlin, pp. 205-222.

Yang, H., Huang, Y., 2003. Preservation of lipid hydrogen isotope ratios in Miocene lacustrine sediments and plant fossils at Clarkia, northern Idaho, USA. Organic Geochemistry 34, 413423.

Zhang, Y.H., Wang, Z.M., Huang, Q., Shu, W., 2008. Phosphoenolpyruvate carboxylase activity in ear organs is related to protein concentration in grains of winter wheat. Journal of Cereal Science 47, 386-391.

Zhou, Y., Grice, K., Stuart-Williams, H., Farquhar, G. D., Hocart, C.H., Lu, H., Liu, W., 2010. Biosynthetic origin of the saw-toothed profile in $\delta^{13} \mathrm{C}$ and $\delta^{2} \mathrm{H}$ of $n$-alkanes and systematic isotopic differences between n-, iso- and anteiso-alkanes in leaf waxes of land plants. Phytochemistry 71, 388-403.

Zhou, Y., Grice, K., Chikaraishi, Y., Stuart-Williams, H., Farquhar, G.D., Ohkouchi, N., 2011. Temperature effect on leaf water deuterium enrichment and isotopic fractionation during leaf 
$924 \quad 72,207-213$.

925 Zhou, Y., Grice, K., Stuart-Williams, H., Hocart, C.H., Gessler, A., Farquhar, G.D., 2016. Hydrogen isotopic differences between $\mathrm{C} 3$ and $\mathrm{C} 4$ land plant lipids: consequences of compartmentation in $\mathrm{C} 4$ photosynthetic chemistry and $\mathrm{C} 3$ photorespiration. Plant, Cell \& Environment 39, 2676-2690. 
Fig. 1: Structure of miliacin.

Fig. 2: (a) Experimental design. $\delta^{2} \mathrm{H}$ and $\delta^{18} \mathrm{O}$ values of the hydroponic solution are those reported in Section 2.1. (b) Sketch of a Panicum miliaceum plant with reference to organs sampled for this study and details of a spikelet (redrawn from Lu et al., 2009).

Fig. 3: Water $\delta^{2} \mathrm{H}$ and $\delta^{18} \mathrm{O}$ values in different organs for distinct hydroponic solution $\delta^{2} \mathrm{H}$ values at 58 and $74 \% \mathrm{RH}$ (Table S2). Considering the analytical precision $\left( \pm 0.1 \%\right.$ for $\delta^{18} \mathrm{O}$ values and $\pm 1 \%$ o 

$n-\mathrm{C}_{31}$ alkane at 36 and $71.2 \%$ relative humidity in various plants (data from Kahmen et al., 2013). 
1 abIe 1: $\mathrm{O}^{-\mathrm{H}}$ and $\mathrm{O}^{\circ \mathrm{U}} \mathrm{U}$ values or water Irom nyaroponic solutions, and non-transpiring (roots and internodes) and transpiring (leaves and panicles) organs in growth chambers at $58 \%$ and $74 \%$ relative humidities. $\delta$ values are averages where replicates exist or are otherwise individual values. Table S2 contains the data for all individual values. HS = hydroponic solution, $\mathrm{NTO}=$ nontranspiring organs, $\mathrm{TO}=$ transpiring organs.

\begin{tabular}{|c|c|c|c|c|c|c|c|c|c|c|c|}
\hline \multirow{2}{*}{\multicolumn{2}{|c|}{$58 \% \mathrm{RH}$}} & \multicolumn{2}{|c|}{$\delta^{18} \mathrm{O}(\% \mathrm{~V}-\mathrm{SMOW})$} & \multicolumn{2}{|c|}{$\delta^{2} \mathrm{H}(\%$ V-SMOW) } & \multirow{2}{*}{\multicolumn{2}{|c|}{$74 \% \mathrm{RH}$}} & \multicolumn{2}{|c|}{$\delta^{18} \mathrm{O}(\% \mathrm{~V}-\mathrm{SMOW})$} & \multicolumn{2}{|c|}{$\delta^{2} \mathrm{H}(\% \mathrm{~V}-\mathrm{SMOW})$} \\
\hline & & Average & Stdev & Average & Stdev & & & Average & Stdev & Average & Stdev \\
\hline \multirow{3}{*}{ 壳 } & HS & -1.1 & & -15 & & \multirow{3}{*}{$\begin{array}{l}\overrightarrow{\breve{u}} \\
\underset{\varpi}{\text { ज }}\end{array}$} & HS & -4.8 & & -36 & \\
\hline & NTO & -1.1 & 0.2 & -18 & 4.6 & & NTO & -4.9 & 0.3 & -37 & 1.4 \\
\hline & TO & 8.7 & 1.6 & 38 & 7.2 & & TO & 7.5 & 4.0 & 0 & 9.8 \\
\hline \multirow{3}{*}{$\begin{array}{l}\stackrel{\sim}{u} \\
\underset{\sigma}{\tilde{\sigma}}\end{array}$} & HS & -2.2 & & 15 & & \multirow{3}{*}{ 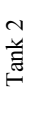 } & HS & -6.6 & & -10 & \\
\hline & NTO & -2.5 & 0.2 & 16 & 1.2 & & NTO & -6.7 & 0.3 & -10 & 0.3 \\
\hline & TO & 7.4 & 2.0 & 51 & 4.8 & & TO & 6.1 & 1.6 & 12 & 2.1 \\
\hline \multirow{3}{*}{ 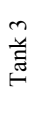 } & HS & -2.4 & & 105 & & \multirow{3}{*}{ 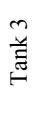 } & HS & -6.6 & & 95 & \\
\hline & NTO & -2.3 & 0.3 & 109 & 2.5 & & NTO & -6.3 & 0.3 & 94 & 1.0 \\
\hline & TO & 6.3 & 3.7 & 88 & 6.2 & & TO & 7.1 & 1.9 & 52 & 3.2 \\
\hline \multirow{3}{*}{ 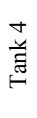 } & HS & -3.5 & & 160 & & \multirow{3}{*}{ 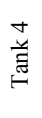 } & HS & -6.8 & & 187 & \\
\hline & NTO & -3.3 & 0.2 & 157 & 5.8 & & NTO & -6.7 & 0.3 & 187 & 1.2 \\
\hline & TO & 4.3 & 1.0 & 118 & 12.3 & & TO & 6.5 & 0.7 & 114 & 2.7 \\
\hline
\end{tabular}


Journal Pre-proofs

1 abIe $L$ : Kegression statistics Ior (a) Figure $\supset$ (tank and plant water $\mathrm{O}^{-} \mathrm{H}$ and $\mathrm{O}^{10} \mathrm{U}$ values); (D) Figure $4\left(\delta^{2} \mathrm{H}\right.$ values of water in HS, organs, miliacin and $n$-alkanes); (c) Figure $5\left(\delta^{2} \mathrm{H}\right.$ values of miliacin and $n$-alkanes versus $\delta^{2} \mathrm{H}$ values of water in transpiring organs); (d) Figure 6 ( $\delta^{2} \mathrm{H}$ values of water in HS and in transpiring organs at two RH). $a$ is the slope, $b$ is the intercept.

\begin{tabular}{|c|c|c|c|c|c|c|c|c|}
\hline \multirow[t]{2}{*}{ (a) Figure 3} & \multicolumn{4}{|c|}{$\mathrm{RH}=58 \%$} & \multicolumn{4}{|c|}{$\mathrm{RH}=74 \%$} \\
\hline & $\mathrm{a}$ & $\mathrm{b}$ & $r^{2}$ & $p$ & $\mathrm{a}$ & $\mathrm{b}$ & $r^{2}$ & $p$ \\
\hline Tank 1 & 5.6075 & -11.462 & 0.9902 & $<0.0005$ & 2.9528 & -22.337 & 0.9911 & $<0.0005$ \\
\hline Tank 2 & 3.4749 & 24.872 & 0.9856 & $<0.0005$ & 1.6498 & 1.3168 & 0.9943 & $<0.0005$ \\
\hline Tank 3 & -2.1234 & 102.23 & 0.8824 & $<0.0005$ & -3.0654 & 74.186 & 0.983 & $<0.0005$ \\
\hline Tank 4 & -5.0907 & 140.57 & 0.8549 & $<0.0005$ & -5.5574 & 149.94 & 0.9939 & $<0.0005$ \\
\hline
\end{tabular}

\begin{tabular}{|c|c|c|c|c|c|c|c|c|}
\hline \multirow[t]{2}{*}{ (b) Figure 4} & \multicolumn{4}{|c|}{$\mathrm{RH}=58 \%$} & \multicolumn{4}{|c|}{$\mathrm{RH}=74 \%$} \\
\hline & $\mathrm{a}$ & $\mathrm{b}$ & $\mathrm{r}^{2}$ & $p$ & $\mathrm{a}$ & $\mathrm{b}$ & $\mathrm{r}^{2}$ & $p$ \\
\hline NTO & 1.0067 & 0 & 0.997 & $<0.0005$ & 1.0056 & -0.87 & 1 & $<0.0005$ \\
\hline TO & 0.45 & 43.8 & 0.95 & $<0.0005$ & 0.48 & 15.5 & 0.963 & $<0.0005$ \\
\hline Miliacin & 0.329 & -69.412 & 0.99 & 0.005 & 0.389 & -108 & 0.981 & 0.01 \\
\hline$n-\mathrm{C}_{25}$ & 0.307 & -111 & 0.953 & 0.024 & 0.404 & -136 & 0.99 & 0.005 \\
\hline$n-\mathrm{C}_{27}$ & n.s. & n.s. & n.s. & 0.18 & 0.477 & -154 & 0.997 & 0.001 \\
\hline$n-\mathrm{C}_{31}$ & 0.326 & -92 & 0.907 & 0.048 & 0.376 & -142 & 0.987 & 0.006 \\
\hline$n-\mathrm{C}_{33}$ & 0.375 & -91.11 & 0.968 & 0.016 & n.s. & n.s. & 0.898 & 0.052 \\
\hline
\end{tabular}

\begin{tabular}{|c|c|c|c|c|c|c|c|c|}
\hline \multirow[t]{2}{*}{ (c) Figure 5} & \multicolumn{4}{|c|}{$\mathrm{RH}=58 \%$} & \multicolumn{4}{|c|}{$\mathrm{RH}=74 \%$} \\
\hline & $\mathrm{a}$ & $\mathrm{b}$ & $r^{2}$ & $p$ & $\mathrm{a}$ & $\mathrm{b}$ & $\mathrm{r}^{2}$ & $p$ \\
\hline Miliacin & 0.725 & -101 & 0.983 & 0.009 & 0.784 & -120 & 0.998 & 0.001 \\
\hline$n-\mathrm{C}_{25}$ & 0.683 & -141 & 0.964 & 0.003 & 0.8 & -148 & 0.971 & 0.015 \\
\hline$n-\mathrm{C}_{27}$ & n.s. & n.s. & n.s. & 0.175 & 0.94 & -167 & 0.967 & 0.017 \\
\hline$n-\mathrm{C}_{31}$ & 0.735 & -125 & 0.97 & 0.015 & 0.748 & -153 & 0.846 & 0.013 \\
\hline$n-\mathrm{C}_{33}$ & 0.83 & -127 & 0.97 & 0.03 & n.s. & n.s. & n.s. & 0.081 \\
\hline
\end{tabular}

\begin{tabular}{ccccc}
\hline (d) Figure 6 & $\mathrm{a}$ & $\mathrm{b}$ & $\mathrm{r}^{2}$ & $p$ \\
\hline $\mathrm{RH}=58 \%$ & 0.448 & 43.824 & 0.947 & $<0.0005$ \\
$\mathrm{RH}=74 \%$ & 0.482 & 15.456 & 0.963 & $<0.0005$ \\
\hline
\end{tabular}


Table 3: $\delta^{2} \mathrm{H}$ values of hydroponic solution (HS) and transpiring organ (TO) (averaged if $>1$ value per tank) waters and miliacin and $n$-alkanes extracted from $P$. miliaceum seeds collected after cultivation at 58 and at $74 \%$ relative humidity in climatic chambers. $n$ corresponds to the number of replicates for each treatment (seeds from 1 to 3 plants per tank) and can vary between compounds depending on the concentration of each compound in the seed extract considered.

\begin{tabular}{|c|c|c|c|c|c|c|c|c|c|c|c|c|c|c|c|c|c|c|}
\hline & \multirow[b]{2}{*}{ Tank } & \multirow{2}{*}{$\begin{array}{c}\mathrm{HS} \\
(\% \text { V-SMOW ) }\end{array}$} & \multirow{2}{*}{$\begin{array}{c}\text { TO } \\
(\% \text { V-SMOW })\end{array}$} & \multicolumn{3}{|c|}{ Miliacin $\delta^{2} \mathrm{H}$} & \multicolumn{3}{|c|}{$n$ - $\mathrm{C}_{25}$ alkane $\delta^{2} \mathrm{H}$} & \multicolumn{3}{|c|}{$n$ - $\mathrm{C}_{27}$ alkane $\delta^{2} \mathrm{H}$} & \multicolumn{3}{|c|}{$n$ - $\mathrm{C}_{31}$ alkane $\delta^{2} \mathrm{H}$} & \multicolumn{3}{|c|}{$n$ - $\mathrm{C}_{33}$ alkane $\delta^{2} \mathrm{H}$} \\
\hline & & & & (\%o V-SMOW) & Stdev & $\mathrm{n}$ & (\%o V-SMOW) & Stdev & $\mathrm{n}$ & (\%о V-SMOW) & Stdev & $\mathrm{n}$ & (\%o V-SMOW) & Stdev & $\mathrm{n}$ & (\%о V-SMOW) & Stdev & $\mathrm{n}$ \\
\hline \multirow{4}{*}{$58 \%$} & 1 & -15 & 38 & -77 & 6 & 3 & -119 & & 1 & -96 & & 1 & -97 & & 1 & -102 & & 1 \\
\hline & 2 & 15 & 51 & -61 & & 1 & -99 & & 1 & -128 & & 1 & -83 & & 1 & -78 & & 1 \\
\hline & 3 & 105 & 88 & -34 & 1 & 2 & -83 & 12 & 2 & -81 & 0 & 2 & -70 & 18 & 2 & -54 & 10 & 2 \\
\hline & 4 & 160 & 118 & -18 & & 1 & -59 & & 1 & -57 & & 1 & -32 & & 1 & -31 & & 1 \\
\hline \multirow{4}{*}{$74 \%$} & 1 & -36 & 0 & -122 & 7 & 3 & -155 & 2 & 2 & -170 & 6 & 3 & -160 & 3 & 3 & -179 & 14 & 3 \\
\hline & 2 & -10 & 12 & -109 & 2 & 2 & -134 & & 1 & -161 & & 1 & -140 & & 1 & -133 & & 1 \\
\hline & 3 & 95 & 52 & -80 & 7 & 2 & -98 & & 1 & -105 & & 1 & -108 & & 1 & -98 & & 1 \\
\hline & 4 & 187 & 114 & -31 & 1 & 3 & -61 & 10 & 2 & -66 & 1 & 2 & -71 & 11 & 2 & -70 & 2 & 2 \\
\hline
\end{tabular}


Table 4: Apparent $\left(\varepsilon_{\mathrm{app}}\right)$ and biosynthetic $\left(\varepsilon_{\mathrm{bio}}\right)$ fractionation for miliacin and $n$-alkanes, calculated from equation 2 and equation 3 , at $58 \%$ and at $74 \%$ relative humidity. $\varepsilon_{\text {bio }}$ values are calculated from $\delta^{2} \mathrm{H}$ values of miliacin and $n$-alkanes (Table 3 ) and $\delta^{2} \mathrm{H}$ values of water in individual transpiring organs (TO; leaves and panicles, Table S2).

\begin{tabular}{|c|c|c|c|c|c|c|c|c|c|c|c|c|c|c|c|c|c|c|c|c|c|}
\hline & \multirow{3}{*}{ Tank } & \multicolumn{5}{|c|}{$\mathcal{E}_{\text {app }}(\%)$} & \multicolumn{15}{|c|}{$\mathcal{E}_{\text {bio }}(\%)$} \\
\hline & & \multirow{2}{*}{ Miliacin } & \multirow{2}{*}{$n-\mathrm{C}_{25}$} & \multirow{2}{*}{$n-\mathrm{C}_{27}$} & \multirow{2}{*}{$n-C_{31}$} & \multirow{2}{*}{$n-\mathrm{C}_{33}$} & \multicolumn{3}{|c|}{ Miliacin } & \multirow[b]{2}{*}{ Median } & \multicolumn{2}{|c|}{$n-\mathrm{C}_{25}$} & \multicolumn{2}{|c|}{$n-\mathrm{C}_{27}$} & \multirow[b]{2}{*}{ Max } & \multicolumn{3}{|c|}{$n-\mathrm{C}_{31}$} & \multicolumn{3}{|c|}{$n-\mathrm{C}_{33}$} \\
\hline & & & & & & & Median & Min & Max & & Min & $\operatorname{Max}$ & Median & Min & & Median & Min & Max & Median & Min & $\operatorname{Max}$ \\
\hline \multirow{4}{*}{$58 \% \mathrm{RH}$} & 1 & -63 & -106 & -82 & -83 & -88 & -112 & -116 & -100 & -153 & -157 & -141 & -130 & -134 & -119 & -131 & -135 & -119 & -136 & -140 & -125 \\
\hline & 2 & -75 & -112 & -141 & -97 & -92 & -106 & -114 & -103 & -142 & -150 & -139 & -169 & -177 & -166 & -127 & -134 & -124 & -122 & -130 & -119 \\
\hline & 3 & -126 & -170 & -168 & -158 & -144 & -112 & -118 & -105 & -157 & -163 & -151 & -155 & -169 & -149 & -145 & -150 & -138 & -131 & -136 & -124 \\
\hline & 4 & -153 & -189 & -187 & -166 & -165 & -124 & -130 & -108 & -161 & -167 & -146 & -159 & -164 & -144 & -137 & -143 & -122 & -135 & -141 & -120 \\
\hline \multirow{4}{*}{$74 \% \mathrm{RH}$} & 1 & -89 & -123 & -139 & -129 & -148 & -127 & -131 & -112 & -160 & -163 & -145 & -175 & -178 & -160 & -164 & -168 & -150 & -184 & -187 & -169 \\
\hline & 2 & -100 & -125 & -153 & -131 & -124 & -120 & -121 & -117 & -145 & -146 & -142 & -171 & -172 & -168 & -150 & -151 & -147 & -144 & -145 & -141 \\
\hline & 3 & -160 & -176 & -183 & -185 & -176 & -125 & -128 & -121 & -143 & -146 & -139 & -149 & -152 & -145 & -152 & -155 & -147 & -142 & -145 & -138 \\
\hline & 4 & -184 & -209 & -213 & -217 & -217 & -130 & -132 & -128 & -156 & -158 & -155 & -161 & -163 & -160 & -166 & -167 & -164 & -165 & -167 & -163 \\
\hline \multicolumn{2}{|c|}{ Overall average } & -119 & -151 & -158 & -146 & -144 & & -118 & & & -151 & & & -158 & & & -145 & & & -144 & \\
\hline \multicolumn{2}{|c|}{ Overall Stdev } & 44 & 39 & 40 & 45 & 43 & & 5 & & & 7 & & & 14 & & & 14 & & & 19 & \\
\hline
\end{tabular}




\section{Declaration of interests}

$\bigotimes$ The authors declare that they have no known competing financial interests or personal relationships that could have appeared to influence the work reported in this paper.

$\square$ The authors declare the following financial interests/personal relationships which may be considered as potential competing interests: 
Figure 1

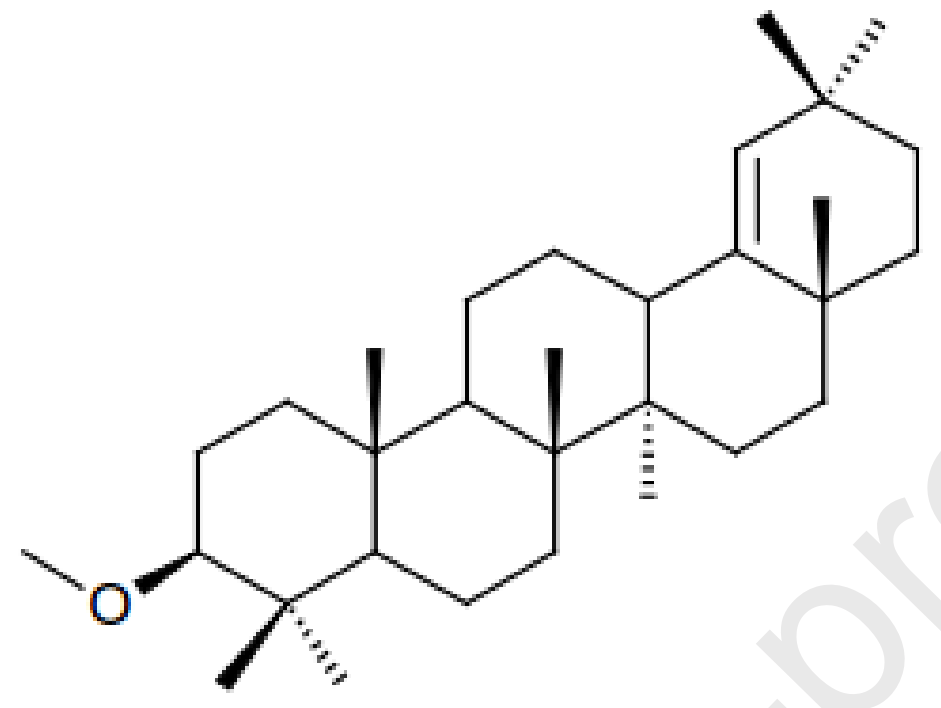


Figure 2

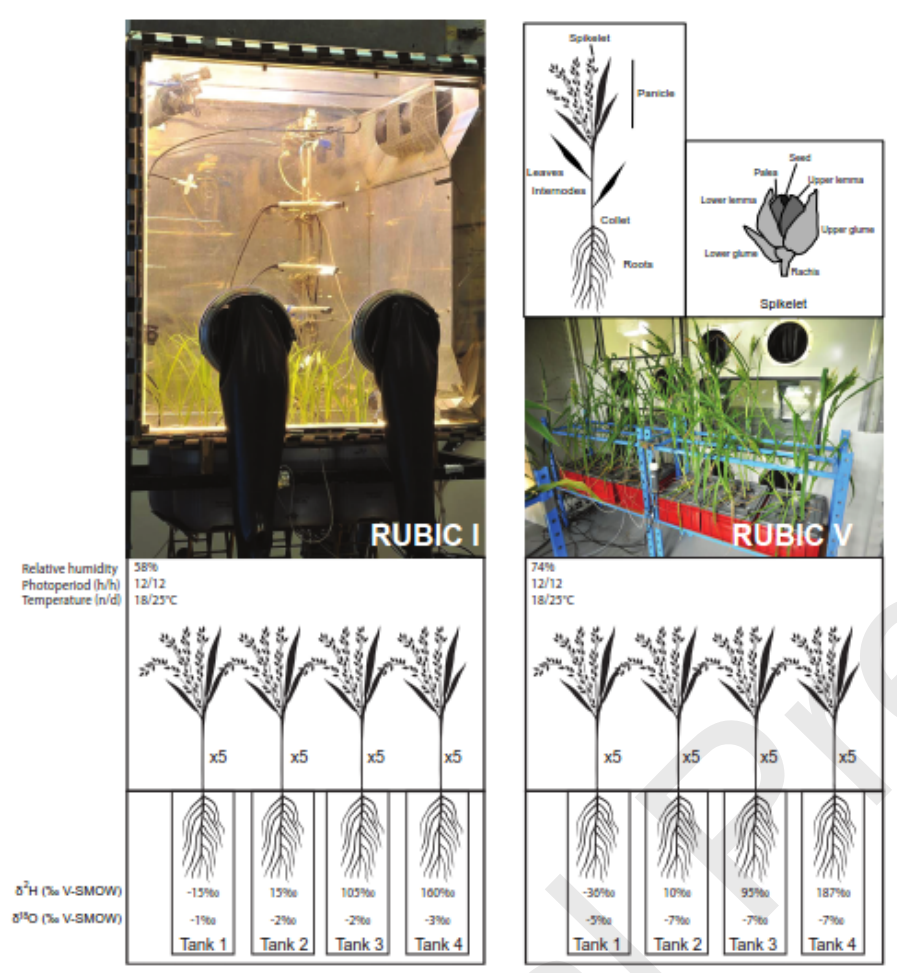


Figure 3

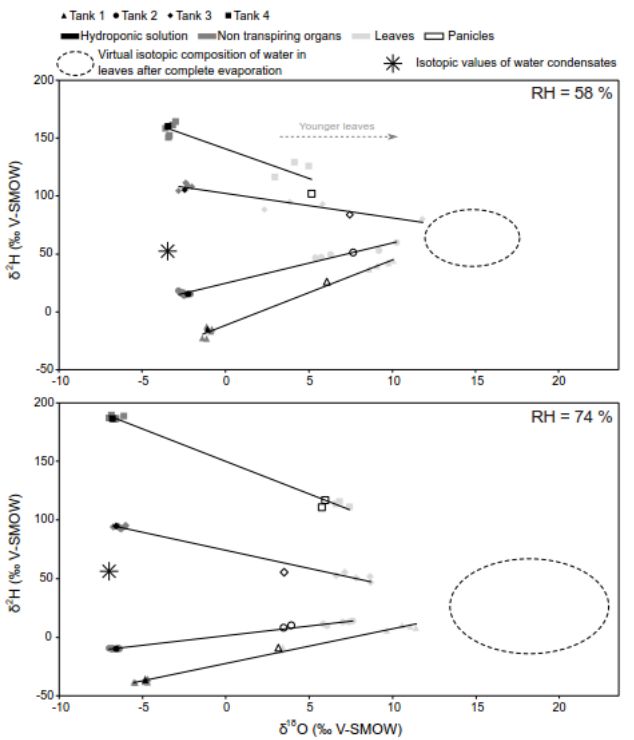



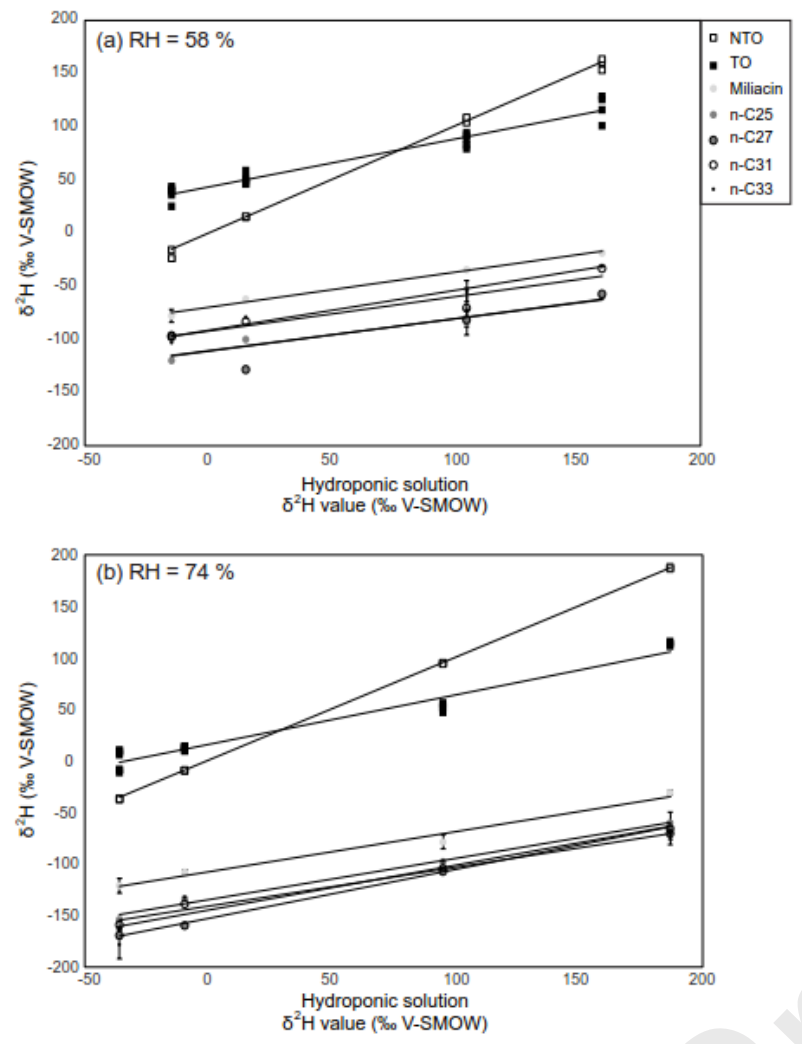

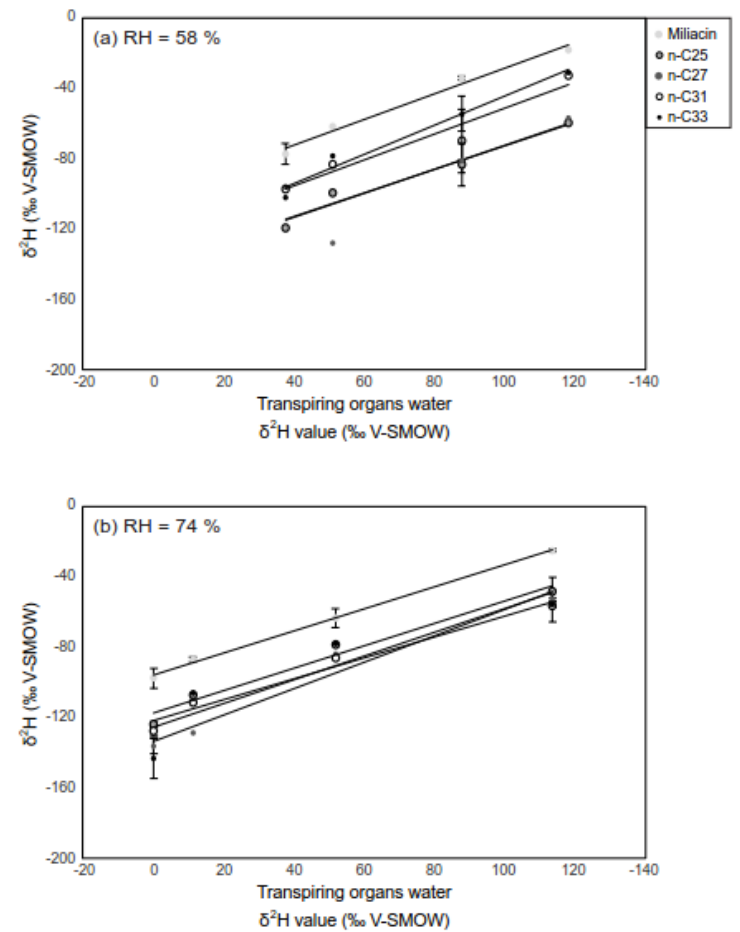


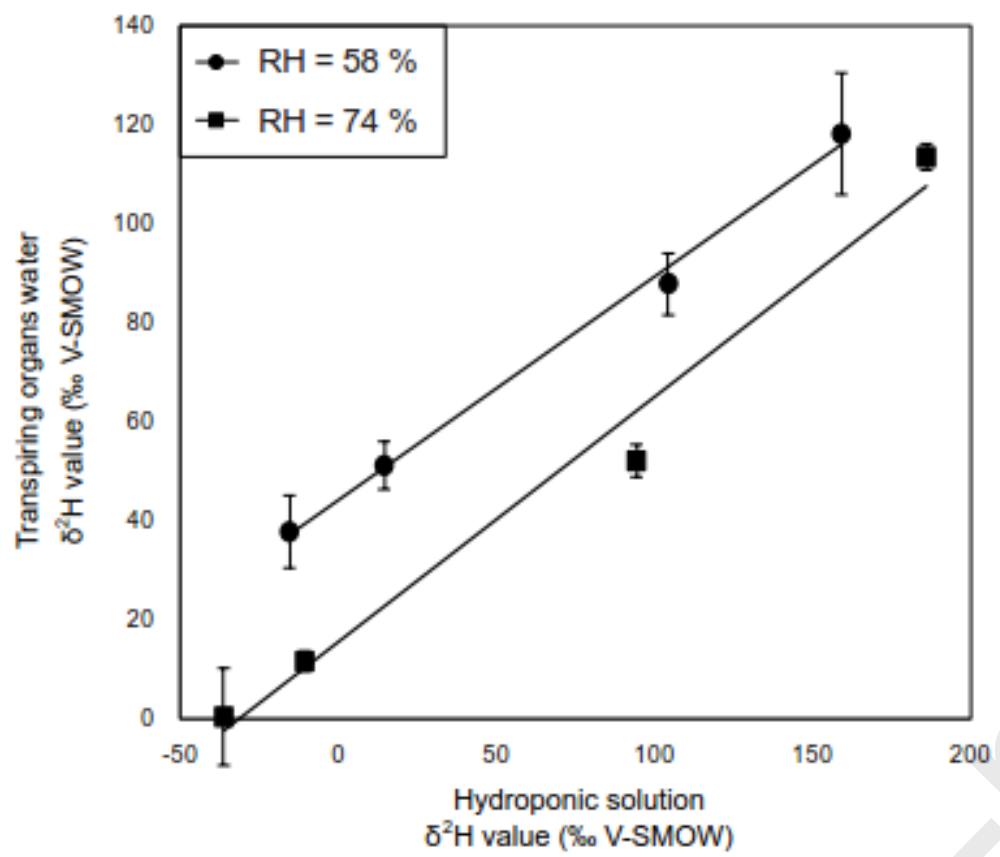




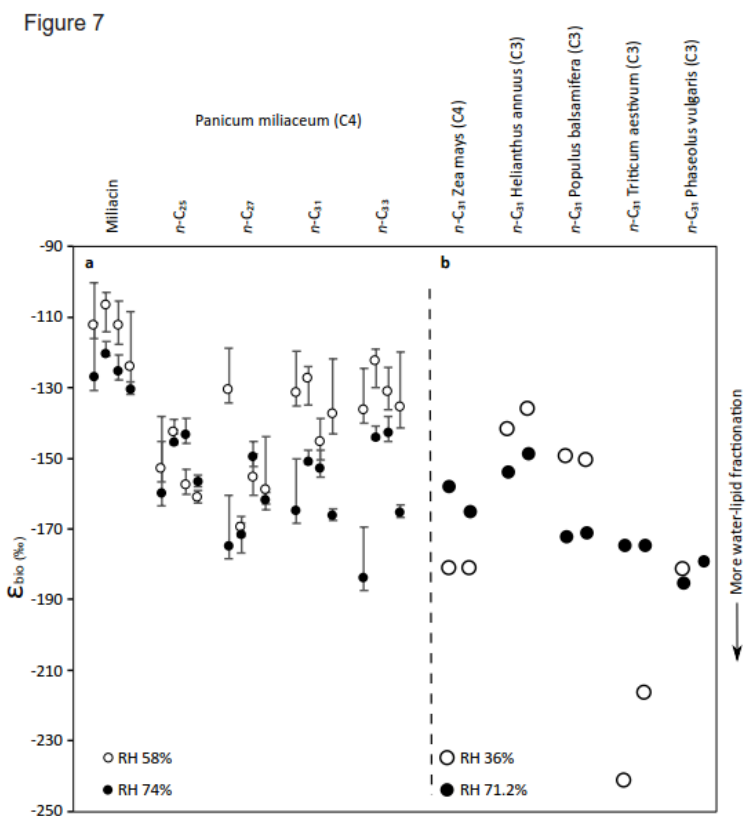

